\title{
Importance of microenvironment and antigen in the regulation of growth and survival of CLL cells
}

\author{
Ann-Charlotte Bergh
}

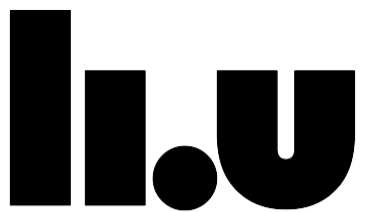

LINKÖPING UNIVERSITY

Division of Cell Biology

Department of Clinical and Experimental Medicine

Linköping University, Sweden

Linköping 2016 
(C) Ann-Charlotte Bergh, 2016

ISSN: 0345-0082

ISBN: 978-91-7685-867-7

The original papers included in this thesis have been reprinted with the permission of respective copyright holder:

Paper I and Paper II: (C) the Ferrata Storti Foundation

Paper III: (C) Macmillan Publishers Limited

Printed by LiU-Tryck, Linköping, Sweden 2016 
"Science never solves a problem without creating ten more" George Bernard Shaw 


\section{SUPERVISOR}

Anders Rosén, PhD, Professor

Division of Cell Biology

Department of Clinical and Experimental Medicine

Faculty of health sciences, Linköping

\section{Co-SUPERVISOR}

Richard Rosenquist Brandell, MD, PhD, Professor

Department of Immunology, Genetics and Pathology

Rudbeck laboratory, Uppsala University, Uppsala

\section{OPPONENT}

Dimitar Efremov, MD, PhD

International Centre for Genetic Engineering and Biotechnology

Molecular Hematology

Rome, Italy 
Chronic lymphocytic leukemia (CLL) cells rapidly die when put in culture implying that microenvironmental signals delivered by accessory cells confer CLL cells with a growth advantage. Recent findings show that CLL cells are antigen experienced and antigen binding play a critical role in the pathogenesis of the disease. The overall aim of this thesis was to study the influence of the microenvironment and antigen binding in CLL.

In paper I, we studied the influence of the small redox-regulatory molecule thioredoxin (Trx) on CLL cell survival and proliferation. We found Trx to be highly expressed in CLL lymph nodes (LNs), secreted from stromal cells surrounding proliferating CLL cells in proliferation centers, indicating growth promoting properties. Secreted Trx was also shown to protect CLL cells from apoptosis.

In paper II, oxidized LDL was added to subset \#1 CLL cells. However, in contrast to our hypothesis, we could not observe activation and proliferation of CLL cells. Instead subset \#1 CLL cells were unresponsive/anergic through the B cell receptor (BcR). This anergic state could however be overcome by "wash out" of bound antigen or addition of toll-like receptor 9 stimulation in some patients.

Gene expression profiles differ between groups of CLL patients and in peripheral blood (PB) and LN compartment, due to different microenvironments. However, it is not known whether these differences also apply for DNA methylation. In paper III, we identified various genes that were alternatively methylated between IGHV mutated (M) and unmutated (UM) groups. For example prognostic genes, CLLU1 and $L P L$, genes involved in B cell signaling, IBTK, as well as numerous TGF- $\beta$ and NF- $\kappa \mathrm{B} / \mathrm{TNF}$ pathway genes.

The intensity and duration of BcR signals are fine-tuned by enhancing or inhibitory coreceptors. SHP-1 inhibits BcR-signals by dephosphorylation. In paper IV, we compared the expression and activity of SHP-1 in CLL cells from LN with matched PB samples. However, in contrast to our hypothesis, SHP-1 activity/phosphorylation status in PB and LN, did not differ significantly.

This thesis, add another piece to the puzzle, on how the microenvironment and antigens influence CLL pathogenesis. Since great variations among individuals are seen, further studies in different groups of patients are necessary to elucidate the importance of antigen for the development of CLL. 


\section{HUR PÅVERKAR MIKROMILJÖN OCH ANTIGEN I LYMFKNUTOR UTVECKLING AV KLL?}

Kronisk lymfatisk leukemi (KLL) är den vanligaste formen av leukemi hos vuxna i västvärlden. Varje år diagnostiseras ca 500 patienter med KLL i Sverige och medianåldern för diagnos är runt 70 år. Det är en heterogen sjukdom, där en del patienter överlever många år utan behandling, medan andra avlider inom bara några få år. Det finns för nuvarande ingen botande behandling för dessa patienter, men utvecklingen av nya läkemedel går snabbt framåt och forskning pågår hela tiden för att utveckla nya effektiva läkemedel. KLL är en sjukdom där en viss typ av immunceller s.k. B-lymfocyter delar sig ohämmat, exakt vilken typ av B-cell som är ursprungscellen eller vad som orsakar och driver sjukdomen är fortfarande inte helt känt och studeras med högsta prioritet av forskare världen över. Flera rapporter visar att KLL-cellerna är beroende av omgivande celler i sin mikromiljö och att de även visar tecken på att ha aktiverats av antigen. Detta har man kommit fram till då man observerat att KLL-cellerna som cirkulerar i blodet är mer vilande jämfört med de leukemiceller som befinner sig i vävnad t.ex. lymfknuta. Där har KLL-cellerna andra celler tätt inpå sig, är mer aktiva och delar sig. Dessutom har man sett att KLL-celler i lymfknutor skiljer sig åt när man tittar på vilka gener som uttrycks. Vår grupp och andra forskargrupper har visat att KLL-antikroppar kan binda till kroppsegna strukturer s.k. autoantigen, men även till främmande strukturer som finns på t.ex. bakterier och virus. En frisk B-cell som befinner sig i lymfknuta ska normalt inte aktiveras av autoantigen (sk. tolerans eller anergi). Vi vet nu att KLL B-celler uppträder annorlunda vid konfrontation med autoantigen dvs. bindning till B-cellsreceptorn, jämfört med friska B-celler. Syftet med min avhandling har varit att få bättre förståelse för varför sjukdomen uppstår, vad som driver utvecklingen av den och mer specifikt att ta reda på hur mikromiljön och antigen är involverat och på vilket sätt det påverkar och aktiverar leukemicellerna. Denna kunskap utgör grunden till hur celldelningen hos leukemicellerna kan stoppas.

I det första delarbetet fann vi att ett litet protein med reduktions-oxidations (redox)egenskaper kallat thioredoxin, frisätts från s.k. stromaceller, som finns runtomkring aktiva, delande leukemiceller i lymfknutan. Vi kunde även se att thioredoxin förbättrade överlevnaden hos leukemicellerna. 
I det andra delarbetet såg vi, tvärtom mot vad vi hade trott, att stimulering av KLLceller från en viss grupp av KLL patienter, med sitt specifika autoantigen (oxiderat LDL), trots sitt aggressiva sjukdomsförlopp, varken gav cellaktivering eller celldelning. Denna brist på cellsvar berodde troligtvis på kronisk tillgång och stimulans av antigen till cellernas receptorer i kroppen. Detta tillstånd kunde dock brytas om antigenet, som redan satt bundet till receptorerna tvättades bort eller om cellerna dessutom stimulerades via andra s.k. toll-liknande receptorer.

Eftersom man tidigare sett att olika undergrupper av patienter med olika sjukdomsstadier, samt celler från blod och lymfknuta, uttrycker olika gener, ville vi i delarbete tre titta på skillnader i DNA-metylering hos dessa grupper. DNA-metylering är ett sätt för celler att reglera geners uttryck, som en "PÅ/AV" knapp. Vi fann många gener som var olika metylerade när vi jämförde celler från patienter med mindre aggressivt sjukdomsförlopp med de som hade ett mer aggressivt förlopp, många av dessa var involverade i cellsignalering Däremot var metyleringsmönstret i princip oförändrat vid jämförelse över tid eller mellan blod och lymfknuta i samma patient.

Eftersom man tidigare sett att B-cellsaktivering via B-cellsreceptorn är viktig för utveckling av KLL samt att dessa signaler skiljer sig mellan blod och lymfknuta, ville vi i delarbete fyra studera ett protein, SHP-1, som reglerar B-cellsreceptorsignalering och jämföra uttryck och aktivitet av detta protein i celler från blod och lymfknuta. Vi kunde dock inte se någon skillnad i uttryck eller aktivitet av proteinet.

Sammanfattningsvis bidrar forskningsprojekten till att öka förståelsen för hur mikromiljön och antigen kan påverka KLL celler. Eftersom sjukdomen är mycket heterogen och ter sig olika hos olika individer krävs mer forskning på olika grupper av patienter för att ta reda på vilken roll antigen spelar för utveckling av sjukdomen. 


\section{LIST OF PAPERS}

This thesis is based on the following Papers, referred to in the text by their Roman numerals (I-IV):

Eva Bäckman, Ann-Charlotte Bergh, Irena Lagerdahl, Björn Rydberg, Christer Sundström, Gerard Tobin, Richard Rosenquist, Mats Linderholm, Anders Rosén. Thioredoxin, produced by stromal cells retrieved from the lymph node microenvironment, rescues chronic lymphocytic leukemia cells from apoptosis in vitro. Haematologica 2007;92: 1495-1504.

Ann-Charlotte Bergh, Chamilly Evaldsson, Lone Bredo Pedersen, Christian Geisler, Kostas Stamatopoulos, Richard Rosenquist, and Anders Rosén. Silenced B-cell receptor response to autoantigen in a poor-prognostic subset of chronic lymphocytic leukemia. Haematologica 2014;99: 1722-30

Nicola Cahill, Ann-Charlotte Bergh, Meena Kanduri, Hanna Göransson Kultima, Larry Mansouri, Anders Isaksson, Fergus Ryan, Karin Ekström Smedby, Gunnar Juliusson, Christer Sundström, Anders Rosén and Richard Rosenquist. 450K-array analysis of chronic lymphocytic leukemia cells reveals global DNA methylation to be relatively stable over time and similar in resting and proliferative compartments. Leukemia 2012;27: 150158.

Ann-Charlotte Bergh, Zahra El-Schich, Payam Delfani, Ohlsson Lars, Anders Rosén and Anette Gjörloff Wingren. B cell receptor signaling suppressor SHP-1 is active in CLL lymph node and peripheral blood. Manuscript 


\section{CONTENTS}

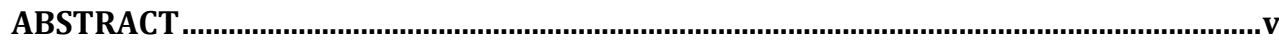

HUR PÅVERKAR MIKROMILJÖN OCH ANTIGEN I LYMFKNUTOR UTVECKLING AV

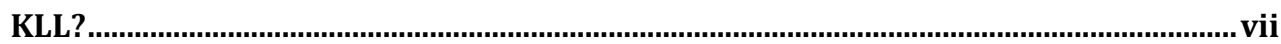

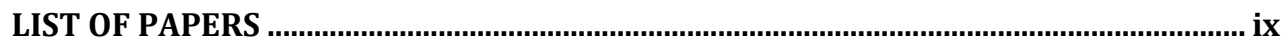

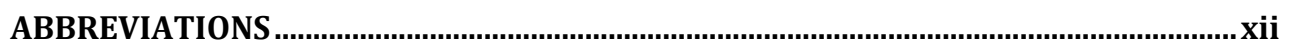

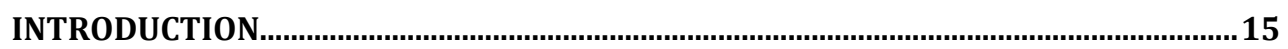

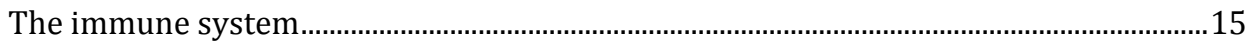

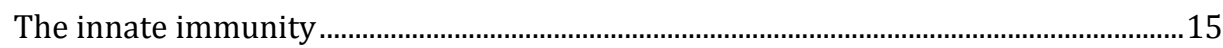

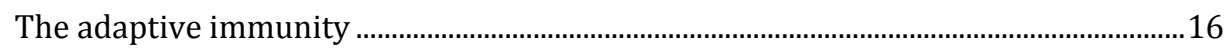

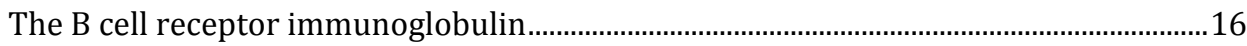

The immunoglobulin structure ................................................................................ 17

B cell development and generation of immunoglobulin diversity ...................................18

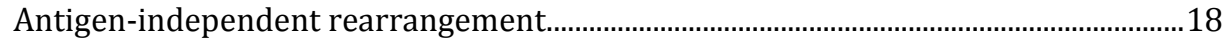

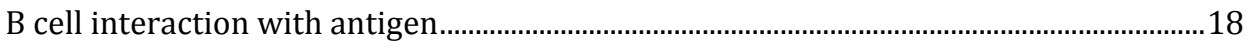

The germinal center reaction........................................................................................ 19

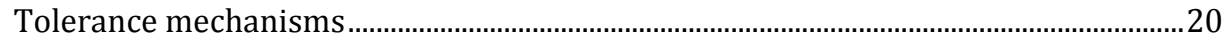

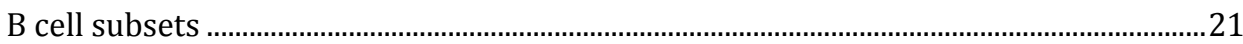

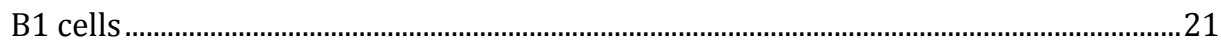

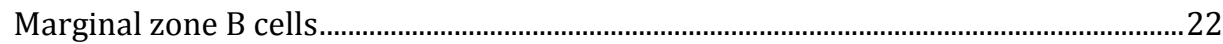

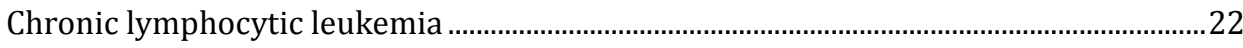

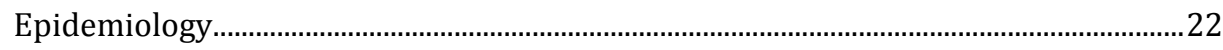

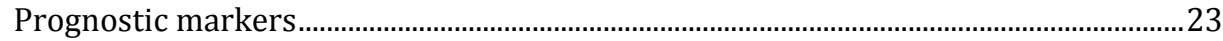

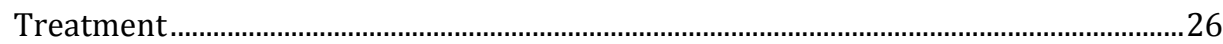

The CLL microenvironment and B cell signaling..........................................................2

Stereotyped B-cell receptors in CLL ................................................................................... 33

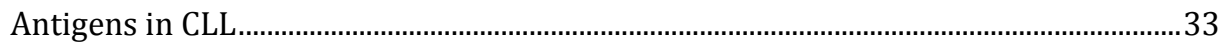

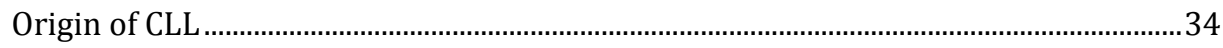

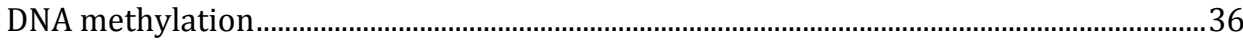

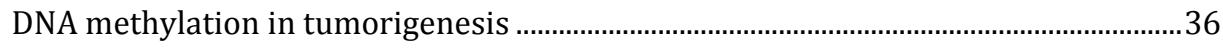

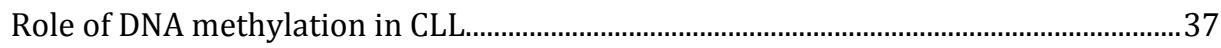

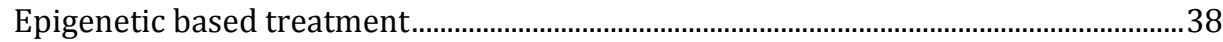




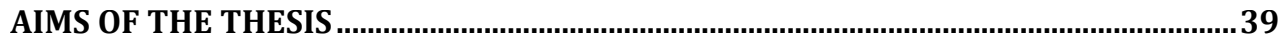

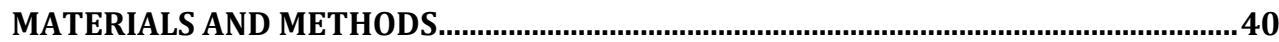

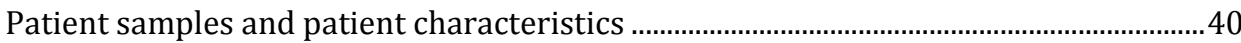

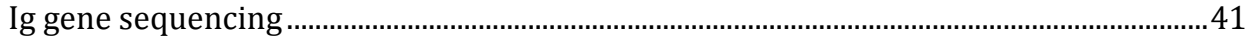

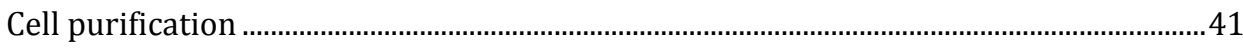

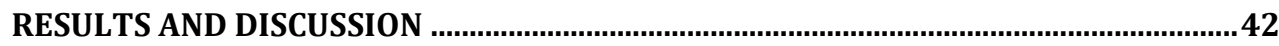

Thioredoxin produced by stromal cells influence CLL cell survival (Paper I) .................42

Chronic autoantigen-BcR engagement induce un-responsiveness/anergy in subset \#1

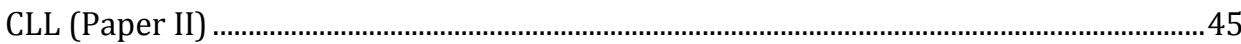

DNA methylation patterns: a comparison between resting and proliferative compartment as well as over time (Paper III) ........................................................................48

SHP-1 expression and activity: comparison of resting and active compartments in CLL

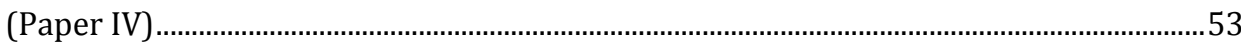

CONCLUSIONS

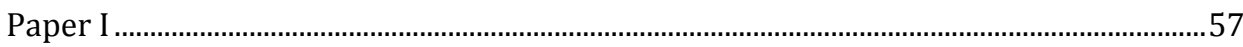

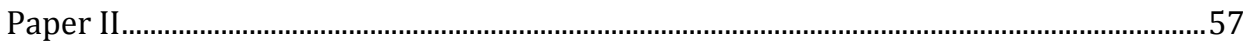

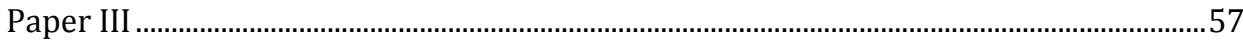

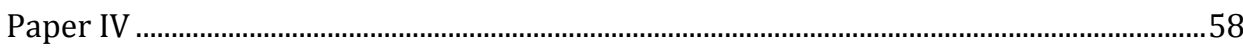

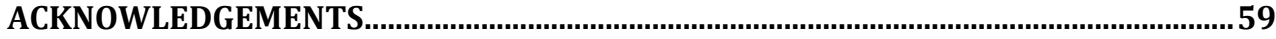

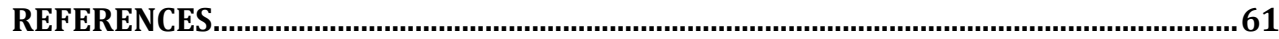




\section{ABBREVIATIONS}

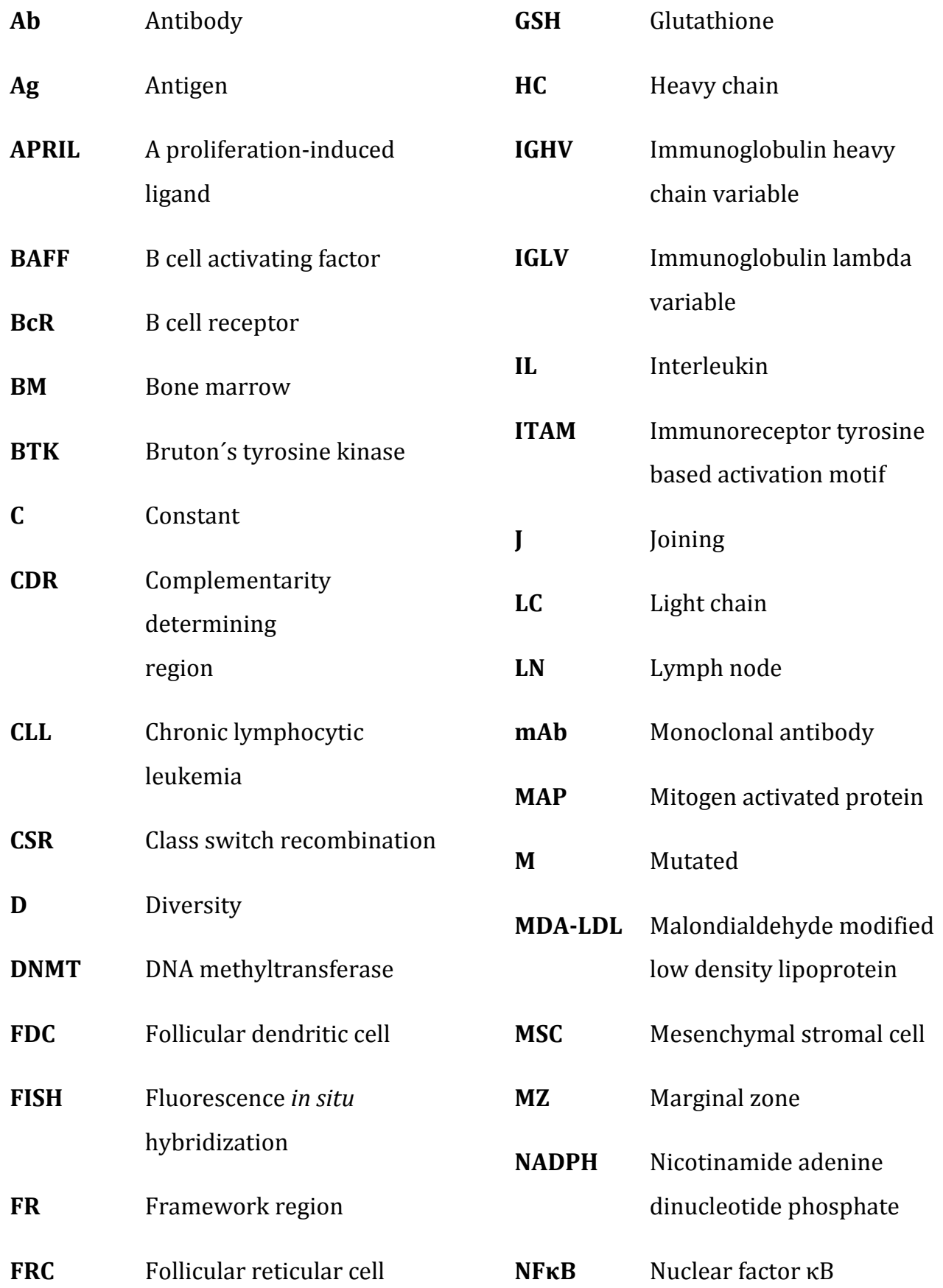




$\begin{array}{llll}\text { NLC } & \text { Nurse-like cell } & \text { PTP } & \begin{array}{l}\text { Protein tyrosine } \\ \text { phosphatase }\end{array} \\ \text { OxLDL } & \text { Oxidized low density } & & \text { Reactive oxygen species } \\ \text { PBMC } & \text { Peripheral blood } & \text { SHM } & \text { Somatic hypermutation } \\ & \text { mononuclear cell } & \text { SYK } & \text { Spleen tyrosine kinase } \\ \text { PC } & \text { Proliferation center } & \text { TLR } & \text { Toll-like receptor } \\ \text { PI3K } & \text { Phosphoinositide 3 kinase } & \text { TrX } & \text { Thioredoxin } \\ \text { PKC } & \text { Protein kinase C } & \text { UM } & \text { Unmutated } \\ \text { PRR } & \text { Pattern recognition } & \text { V } & \text { Variable } \\ & \text { receptor } & \text { ZAP70 } & \text { 70 kDa zeta chain } \\ \text { Pre-B cell } & \text { Precursor B cell } & & \text { associated protein kinase }\end{array}$

Pro-B cell Progenitor B cell 


\section{INTRODUCTION}

Chronic lymphocytic leukemia (CLL) is characterized by an accumulation of long-lived, monoclonal B-lymphocytes infiltrating bone marrow (BM), peripheral blood (PB) and lymphoid tissue. There is currently no curative treatment.

Over the last decade, immunogenetic analysis of B cell receptor immunoglobulins (BcR IGs), which resulted in the observations that groups of CLL patients share remarkable similar IG gene rearrangements, have revolutionized the field of CLL. These studies highlights the BcR as a key-player in CLL, and the hypothesis that antigens (Ags) play a critical role in the pathogenesis was put forward (1-3).

In this thesis I will focus on the interplay between the malignant CLL B cells and tumor microenvironment as well as the role for Ags in the leukemogenesis. For you to understand these parts, I will first guide you through the basics of the immune system, BcR structure, normal B cell development and interaction with Ag.

\section{The immune system}

The immune system is composed of two subdivisions; the innate immune system and the adaptive immune system.

\section{The innate immunity}

The innate, non-adaptive defenses form the earliest barriers to infection. Most microorganisms that we come into contact with are destroyed by innate defense mechanisms. Innate immune responses are not specific to a particular pathogen (as the adaptive immune responses are) but depend on proteins and phagocytes that recognize conserved structures on pathogens. The first barriers are physical such as skin and mucosal surfaces or chemical such as secretion of antimicrobial peptides. If the pathogen should pass these barriers inflammation occurs and the complement system is activated. The complement system helps to clear the pathogens by recruiting phagocytes, mediating uptake through complement receptors or by causing direct lysis of the pathogen. 
Recruited phagocytes bear pattern recognition receptors (PRRs), such as scavenger receptors (SC) and toll-like receptors (TLRs), that recognize repetitive structures on bacteria, and pathogen-associated molecular patterns (PAMPs) such as bacterial DNA which contains unmethylated repeats of dinucleotide $\mathrm{CpG}$ and viral double-stranded RNA $(4,5)$. Recent studies have shown that besides pathogen-derived ligands, PRRs can also recognize self-derived ligands such as oxidation-specific epitopes formed during apoptosis and oxidation (6). These epitopes can also be recognized by natural antibodies (Abs) produced by innate B cells.

\section{The adaptive immunity}

The adaptive immune system is triggered when a pathogen evades the innate immune system and generates a threshold level of Ags. The adaptive immune responses are initiated in the local lymphoid tissue in response to Ags presented by dendritic cells. Agspecific $\mathrm{T}$ cells and $\mathrm{Ab}$ secreting $\mathrm{B}$ cells are generated by clonal expansion and differentiation.

\section{The B cell receptor immunoglobulin}

B cells originate and mature in the BM, they account for $10-15 \%$ of circulating lymphocytes and are the main component of the adaptive immune system with its chief functions being $\mathrm{Ag}$ presentation and $\mathrm{Ab}$ production in order to eliminate foreign pathogens (7). The human body makes millions of B lymphocytes each day that circulates in the blood and in the lymphatic system as naïve B cells that play a role of surveillance in the immune system. Each B cell has a unique BcR on its surface that recognizes Ags on foreign pathogens. Upon encounter and BcR-binding to the specific Ag, the naïve B cell undergoes $\mathrm{Ab}$ affinity maturation and differentiates either into a long-lived memory $\mathrm{B}$ cell or an Ab secreting plasma cell. The BcR is also an active and dynamic signal transmitter that forwards signals from the surrounding microenvironment, which can induce the cell to proliferate, become anergic, edit its BcR or undergo apoptosis. The outcome of $\mathrm{Ag}$ stimulation depends on multiple factors such as the cells in the surrounding microenvironment, co-receptor interaction, and the type and affinity of the Ag. 


\section{The immunoglobulin structure}

The IG molecule is composed of four polypeptide chains, two identical light chains (LC) and two identical heavy chains (HC) (Figure 1). Each chain has both a variable (V) and a constant (C) region. The four chains are joined in the final IG molecule to form a flexible Y-shape. At the tip of each arm of the Y-shaped molecule is an area called the Abcombining site, which is formed by a portion of the HC and LC. The V domain of IG HC is encoded by 3 types of genes called variable (IGHV), diversity (IGHD) and joining (IGHJ), while the V domain of LCs is encoded by IGKV/IGLV and IGKJ/IGLJ genes only. Each V domain can be split into four regions of relatively constant sequences termed the framework regions (FRs) and three regions with high sequence variability, termed the complementarity determining regions (CDR1, CDR2 and CDR3). The CDR3 is at the junction of the IGHV-IGHD-IGHJ genes and has the highest variability. Constant regions have essentially the same amino acid sequence in all Ab molecules of the same class (IgG, $\operatorname{IgM}, \operatorname{IgD}, \operatorname{IgA}$, or IgE) and specifies the isotype of the Ig and exert various effector functions (8-10).

Immunoglobulin heavy chain

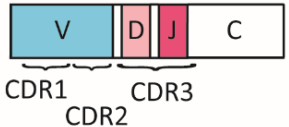

Immunoglobulin light chain

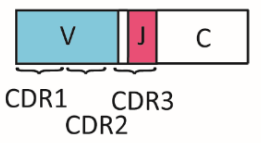

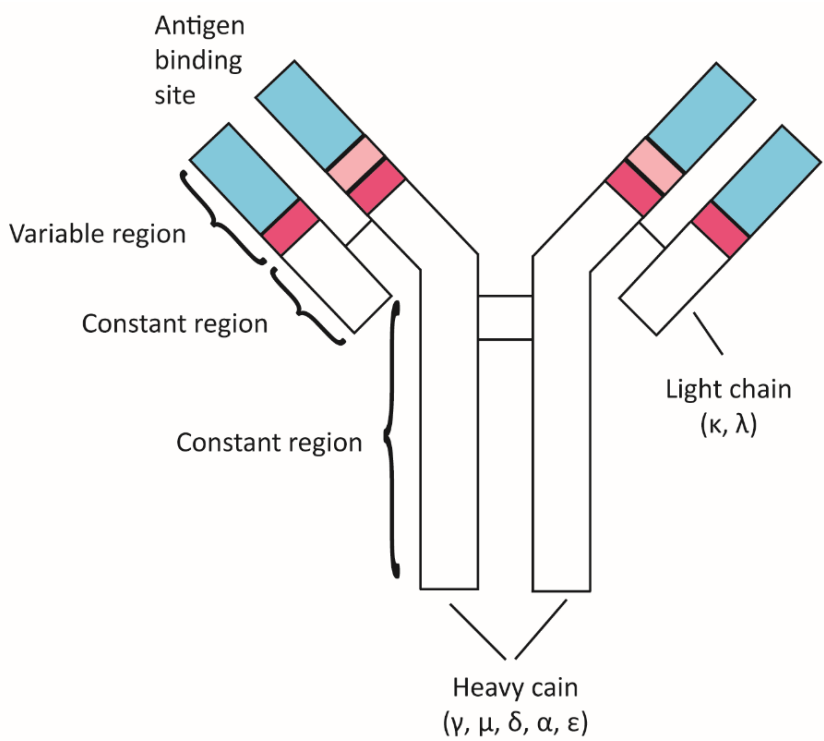

Figure 1. Immunoglobulin structure 


\section{B cell development and generation of immunoglobulin diversity}

\section{Antigen-independent rearrangement}

Early B cell development occurs stepwise in the bone marrow and is dependent on interaction with the surrounding stromal cells for their differentiation and proliferation. The earliest B-lineage cells are called progenitor B cells (pro-B cells) and derive from lymphoid stem cells. Pro-B cells express the surface markers CD19 and CD43. It is in this developmental stage the IGHV gene rearrangement starts with the joining of an IGHD gene to an IGHJ gene, followed by the joining of an IGHV gene to the rearranged IGHDIGHJ genes in the late pro-B cell. Productive IGHV-IGHD-IGHJ rearrangement leads to expression of a precursor (pre)-BcR which in combination with a surrogate light chain is found both in the cytoplasm and on the surface of the large pre-B cell. Signaling through this receptor induces cell division, giving rise to small pre-B cells in which the rearrangement of the IGH locus halts and the light-chain rearrangement starts. The smallpre-B cell now loses the surface expression of CD43 but retains the expression of CD19. Once a productive light chain, $\kappa$ or $\lambda$, is produced, a complete IgM-molecule is expressed on the cell surface and together with signaling chains, $\operatorname{Ig} \alpha$ and $\operatorname{Ig} \beta$ a functional BcR complex is formed $(7,11,12)$. The cell is now defined as an immature B cell. The BcR is now tested for central tolerance to self-Ags. If the B cell turns out to be strongly selfreactive, depending on the nature of the $\mathrm{Ag}$, the cells can have different fates; either they die through apoptosis or clonal deletion, produce a new receptor through receptor editing, or become anergic. Immature B cells that do not bind strongly to self-Ags are allowed to mature, leave the BM and migrate to the spleen as a mature naïve B cell (7). The primary repertoire of IGs that takes place without Ag involvement has been formed.

\section{B cell interaction with antigen}

B cell activation requires two distinct signals, and results in B cell differentiation into memory B cells or plasma cells. The first activation signal occurs upon Ag binding to the $\mathrm{BcR}$. Upon binding to the $\mathrm{BcR}$, the Ag is internalized by receptor-mediated endocytosis, digested, and complexed with MHC II molecules on the B cell surface (13). The second activation signal occurs either via a T-dependent or a T-independent (TI) mechanism. Most B cell responses to Ag require the interaction of B cells with T helper cells. Activated 
T cells provide a second activation signal to the B cell, which can occur through a variety of proteins. However, there are a few types of TI Ags that can directly provide the second B cell activation signal, i.e. type 1 (TI-1) and type 2 (TI-2) (13). While secondary signals in a TI-1 response can be given by TLRs, TI-2 Ags usually contains highly repetitious molecules such as bacterial or viral polysaccharides, which can extensively cross-link the $\mathrm{BcR}$ and thus activate the B cell (14).

\section{The germinal center reaction}

Germinal centers (GCs) are important sites of B cell clonal expansion, somatic hypermutation (SHM), and affinity based selection, which in the end results in in the production of high affinity Abs (Figure 2) (15). Upon encounter with Ag in the circulation or in the primary follicle the naïve B cell migrate to the T cell zone of the lymphoid tissue. In the $\mathrm{T}$ cell zone the B cell becomes fully activated after interaction with CD4+ $\mathrm{T}$ cells and Ag-presenting cells $(15,16)$. The Ag selected B cells are induced to differentiate into short-lived $\mathrm{Ab}$ producing cells or enter GCs. Ag activated cells differentiate into centroblasts which undergoes clonal expansion and forms the dark zone of the GC. During proliferation the centroblasts undergo the second phase of IG diversification which is achieved by SHM, and class switch recombination (CSR). SHM introduces single nucleotide exchanges into the rearranged IGV region, giving rise to mutated BcRs on the surface of the B cell with altered Ab affinity for Ag $(17,18)$. SHM is associated with DNA strand breaks and requires the activity of activation-induced cytidine deaminase (AID) (18). Eventually some centroblasts reduce their rate of division, differentiate into centocytes and move to the light zone. In the light zone these smaller non-dividing centocytes are situated in a mesh of follicular dentritic cells (FDCs), $\mathrm{T}$ cells and macrophages. Clones with the highest affinity for Ag are favored for survival and develops into $\mathrm{Ab}$-secreting cells. In CSR the original $\mathrm{C}$ region is replaced by an alternative $\mathrm{C}$ region, in this way the functional diversity of the IG repertoire is increased. The first Ag receptors expressed on a B cell are of IgM and IgD isotypes. Later in an immune response the same assembled V region can be expressed in IgG, IgA or IgE Abs. Ag selected centrocytes eventually differentiate into memory or plasma cells $(15,19,20)$. 


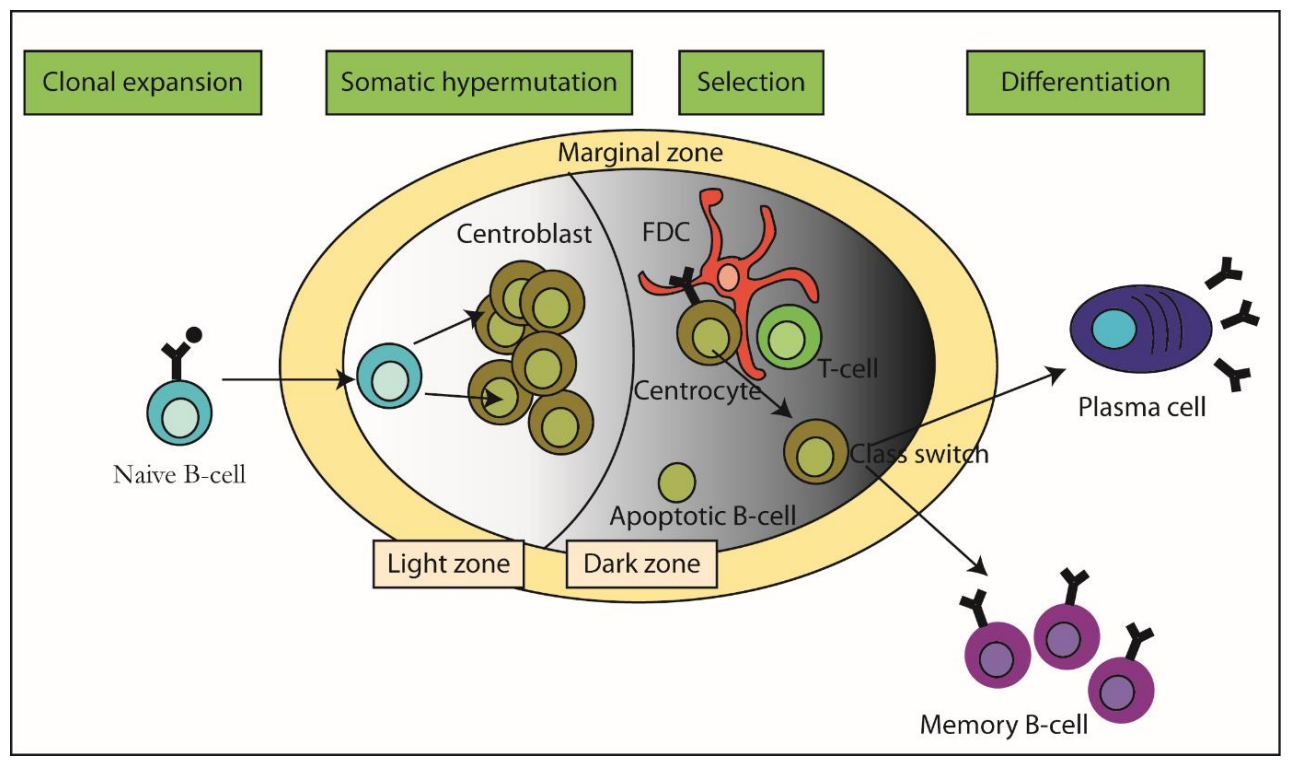

Figure 2. Germinal center reaction

\section{Tolerance mechanisms}

About $50-75 \%$ of newly generated B cells are autoreactive and must be silenced by tolerance mechanisms to prevent autoimmune diseases $(21,22)$. This silencing is known to occur by three different mechanisms; receptor editing, clonal deletion or anergy, while anergy seem to be the most common mechanism used $(23,24)$. Receptor editing occurs when the primary IG gene rearrangement is modified so that it gains different specificity, by undergoing a secondary LC rearrangement at the IGK or IGL locus. If the cells fail to eliminate high affinity for self, the cells undergo clonal deletion, which is mediated by apoptosis of the autoreactive cells in the BM $(25,26)$. The decision of which silencing mechanism to use is dependent on receptor affinity, and autoantigen avidity. Higher avidity favors deletion and editing. Low avidity favors anergy. The immune system is constantly challenged to discriminate between self vs non-self and mediate the right response. Ag binding to cell surface Ag-receptors in combination with secondary signals from i.e. CD40L, cytokines, chemokines or TLR agonists leads to transduction of downstream signaling pathways. Chronic Ag-receptor stimulation in the absence of secondary signals however leads to anergy (27). Chronic BcR stimulation induce biased mono-phosphorylation of immune receptor tyrosine based activation motifs (ITAMs) which in turn lead to biased activation of Lyn. Lyn activate inhibitory signaling pathways 
involving SH2-domain-containing protein tyrosine phosphatase 1 (SHP-1) and SH2domain-containing inositol polyphosphate 5' phosphatase (SHIP). Anergized B cells are characterized by low SIgM, as a result of constant BcR internalization and recycling, elevated basal intracellular $\mathrm{Ca}^{2+}$ concentration, and subsequent constitutive activation of extracellular signal-regulated kinase (ERK)1/2 (28).

\section{B cell subsets}

In humans, different B cell subpopulations can be distinguished in peripheral blood and other tissues on the basis of differential expression of various surface markers. These different subsets correspond to different stages of maturation, activation and differentiation and play different roles in the immune system. B1 cells or marginal zone (MZ) B cells have been discussed as potential origin for CLL. These subsets are described below.

\section{B1 cells}

B1 cells have been best described in mouse and the identity and existence of a human counterpart to murine B1 cells have been debated. B1 cells play critical roles in immediate defense against microbial invasion and in housekeeping scavenging of cellular debris (29-32). They are the main producers of natural IgM Abs, which are germline encoded, highly polyspecific, spontaneous secreted in the absence of infection and bind to both self-Ags and microbial Ags (33-35). B1 cells are the main B cell population in the peritoneal and pleural cavities. They develop earlier than follicular (B2) cells hence the name B1. In addition B1 cells differ functionally from B2 cells in efficiently presenting Ag to $\mathrm{T}$ cells, furthermore they show some similar characteristics to anergic B cells, such as tonic signaling with high cytoplasmic free $\mathrm{Ca}^{2+}$ concentration in the absence of specific stimulation. They are non-responsive to BcR engagement and cannot mobilize $\mathrm{Ca}^{2+}$ or proliferate in response to BcR-cross-linking. Instead they have an enhanced ability to respond to innate immune signals such as TLR agonists (36-39). Two subpopulations have been found in mice; B1a and B1b. Both subsets share phenotypic characteristics and are $\mathrm{CD} 19{ }^{\text {hi }} \mathrm{CD} 45^{\mathrm{lo}} \mathrm{CD} 43^{+} \mathrm{CD} 23-\mathrm{IgM}^{\mathrm{hi}}{ }^{\mathrm{IgD}}{ }^{\mathrm{lo}}$. B1a cells express CD5, while B1b cells do not (36). B1b cells are regulated separately from B1a and also have distinct functions. IGHV gene usage is much more restricted in B1 cells than adult B2 cells. B1 cells secrete Abs that are specific for self-Ags such as oxidized lipids and Ags on apoptotic cells. In addition 
B1 cell derived Abs have specificity for pathogen expressed molecules such as phosphorylcholine and LPS. Recently, Griffin et al (40) found a small subset of B cells in human PB and cord blood that express CD20, CD27 and CD43 that show several functional characteristics similar to murine B1 cells. The main characteristics of this cell population were spontaneous IgM secretion, efficient $\mathrm{T}$ cell stimulation, and tonic intracellular signaling. An intense debate is still going on however if these "human B1 cells" really are true B1 or if they are pre-plasmablasts (41-44).

\section{Marginal zone B cells}

Marginal zone (MZ) B cells reside foremost in the MZ of the spleen but in humans they can also be found circulating in blood. MZ-like regions exist also in tonsil subepithelial areas, dome regions of Peyer patches, and subcapsular regions of LNs. They are characterized by a sIgM ${ }^{\text {high }}, \operatorname{sIgD}^{\text {low }}, \mathrm{CD}^{2} 7^{+}, \mathrm{CD} 23^{-}, \mathrm{CD} 21^{+}, \mathrm{CD} 1^{+}, \mathrm{CD}^{-}$phenotype. Pathogens reaching the blood-stream are efficiently trapped in the MZ by macrophages, MZ B cells then respond rapidly to the pathogens, in a T cell independent way, by developing into plasmablasts which secrete IgM. They can express either mutated or unmutated IGVs however, about $90 \%$ of all MZ B cells bear SHM (45).

\section{Chronic lymphocytic leukemia}

\section{Epidemiology}

CLL accounts for about 30\% of mature B cell malignancies (46) and is the most common form of adult leukemia in the Western countries with approximately 500 cases diagnosed annually in Sweden. The incidence rate is twice as high in men compared to women with a median age at diagnosis of 72 years (47-49). Few, if any, environmental factors have been linked to CLL, rather there seem to be a genetic and familial predisposition for the pathogenesis of the disease. Epidemiological studies show that there is a familial susceptibility in approximately $5-10 \%$ of cases (50). Furthermore the disease has been shown to appear more frequently in certain geographic areas, Western Europe and North America and is very rare in for example Asia $(51,52)$. 
CLL is characterized by the accumulation of high numbers of long-lived, monoclonal B lymphocytes infiltrating BM, PB, and lymphoid tissue. The characteristic immunophenotype of lymphoid cells in CLL is weak surface IgM, with or without IgD, positive for surface CD5, CD19, CD20 (weak), CD22 (weak), CD79a, CD23, CD43 (53, 54). Immunophenotyping is used as a diagnostic criteria as well as a lymphocytosis of $>5 \times 10^{9}$ B lymphocytes/L in PB (55). Clinical staging can be performed according to Binet or Rai staging systems (Tables 1 and 2 respectively) $(56,57)$.

Table 1. Clinical staging according to Binet (56)

\begin{tabular}{|c|c|c|c|}
\hline Stage & $\begin{array}{c}\text { Number of } \\
\text { involved lymph } \\
\text { node areas }\end{array}$ & Hemoglobin g/L & Platelets x10 $/ \mathbf{L}$ \\
\hline A & $<3$ & $>100$ & $>100$ \\
B & $>2$ & $>100$ & $>100$ \\
C & any & $<100$ & $<100$ \\
\hline
\end{tabular}

Table 2. Clinical staging according to Rai (57)

\begin{tabular}{|c|c|c|c|c|c|}
\hline Stage & $\begin{array}{c}\text { Blood and bone } \\
\text { marrow } \\
\text { involvement }\end{array}$ & Lymphadenopathy & $\begin{array}{c}\text { Splenomegaly } \\
\text { or } \\
\text { hepatomegaly }\end{array}$ & $\begin{array}{c}\text { Hemoglobin } \\
\text { g/L }\end{array}$ & $\begin{array}{c}\text { Platelets } \\
\mathbf{x 1 0} / \mathbf{L}\end{array}$ \\
\hline $\mathbf{0}$ & Yes & No & No & $>109$ & $>99$ \\
I & Yes & Yes & No & $>109$ & $>99$ \\
II & Yes & Yes or No & Yes & $>109$ & $>99$ \\
III & Yes & Yes or No & Yes or No & $<110$ & $>99$ \\
IV & Yes & Yes or No & Yes or No & any & $<100$ \\
\hline
\end{tabular}

\section{Prognostic markers}

Prognostic factors traditionally used in the clinic are Rai and Binet and the lymphocyte doubling time (LDT: the time required for doubling of the absolute lymphocyte count). Although these factors are helpful in defining the extent of the disease and of disease progression, they cannot predict the long-term clinical prognosis of patients with lowstage disease, which today concerns the majority. The variability in the clinical course of CLL has driven researchers to look for better prognostic markers that can be used for CLL prognostication and can lead to a more individualized treatment strategy. Several prognostic markers based on genetic, phenotypic, and molecular characteristics of CLL B cells have emerged in the past decade. 


\section{IGHV gene analysis}

The fact that half of the CLL patients have somatically mutated IGHV genes was already reported in 1994 (58). In 1999 the prognostic importance of this characteristic was demonstrated by two independent groups $(59,60)$. They showed that CLL patients with mutated (M) IGHV genes had a median overall survival significantly longer compared with patients with unmutated (UM) IGHV genes. A cut-off of more than or equal to $98 \%$ identity to the corresponding germline IGHV gene is classified as UM. IGHV mutational status is a reliable marker and does not change over time, it is an established and commonly used prognostic marker in CLL.

\section{Expression of biomarkers}

CD38 is a transmembrane glycoprotein expressed on the surface of B cells and other immune cells. It is involved in interaction with the microenvironment, cell-signaling, adhesion and $\mathrm{Ca}^{2+}$-flux (61). CD38 has been of much interest as a prognostic marker in CLL. Patients with a high percentage within the CLL clone of CD38 positive cells are more prone to activation, are more often IGHV UM and have a more aggressive disease. In contrast those with CD38 negative cells have M IGHV genes, a more indolent disease course, requires no or minimal treatment and have a longer survival $(59,62)$. Further studies by others have revealed however, that this correlation with the IGHV mutational status is not absolute and that CD38 expression may change over time (63). Furthermore, there are also discussions on which is the best cut-off value for determining positivity. The initial cut-off value of $30 \%$ was later lowered to $20 \%$ and then to $7 \%(64,65)$. Nonetheless, despite these controversies, CD38 expression has proven to be a valuable prognostic marker in CLL.

ZAP70 (70-kDa zeta-chain-associated protein kinase) is an intracellular protein important for cell signaling. It was first described in T cells and natural killer cells, but was later also found in normal B cells, particularly when activated (66-68). ZAP70 was identified to be expressed in CLL B cells and also to be the most differentially expressed gene when CLL patients with M and UM IGHV genes were compared, high expression level of ZAP70 have been shown to correlate to a more aggressive disease $(69,70)$. Although it is a valuable independent prognostic marker, there has been problems with the standardization of the protocol and techniques used for ZAP70 analysis. 


\section{Genomic aberrations}

Chromosomal aberrations have been found by fluorescence in-situ hybridization (FISH) technique in $82 \%$ of CLL patients, however no common single genetic aberration have been found in all CLL cases (71).

Deletion at 13q14 is the most frequently occurring chromosomal aberration, occurring in approximately $55-60 \%$ of all cases (71). It is, as sole aberration, associated with a favorable prognosis and indolent disease course. It was recently discovered that deletion of this region is associated with the loss of microRNAs (miRNAs), miR15a and miR16-1 (72). miR15a/16-1 negatively regulates the expression of the anti-apoptotic protein BCL2 and the deletion of these miRNAs correlates with overexpression of the BCL2 gene (73).

Deletion at 11q is the second most common alteration in CLL and occurs in about 12$18 \%$ of cases, most often in patients with UM IGHV, and is associated with poor clinical outcome (71). The Ataxia telangiectasia mutated (ATM) gene is identified as the most likely candidate gene in del(11q) CLL. ATM is crucial for DNA repair and known to play a role in activating p53 (74).

Trisomy 12 is the third most common alteration and occurs in about $11-16 \%$ of cases (71). It is associated with an intermediate survival and shorter time to treatment. Trisomy 12 has recently been shown to be associated with mutations in the NOTCH1 gene $(75,76)$.

Deletion of 17p occurs in about 7\% of CLL cases (71) and patients with this aberration always suffer from a very aggressive clinical course and chemotherapy resistance, because of loss of TP53. Most patients with del(17p) carry mutations within the remaining TP53 allele $(77,78)$. The p53 tumor suppressor protein plays a key role in inducing apoptosis and cell cycle arrest after DNA damage (79).

\section{Novel mutations}

In recent years, with new generation sequencing (NGS) technique available, researchers have been able to find several new mutated genes with prognostic value. Some of these genes include NOTCH1, MYD88, SF3B1 and BIRC3 $(75,80-83)$. NOTCH1 and SF3B1 will be described below. 
NOTCH1 mutations, a ligand activated transcription factor gene, occur in about 8-12\% of patients at diagnosis and have been associated with a shorter time to first treatment and shorter overall survival $(75,76)$. A high frequency of NOTCH1 mutations have been found in patients with trisomy $12(84,85)$.

Mutations of the $\underline{\boldsymbol{S F} 3 \boldsymbol{B 1}}$ gene were documented in 5-17\% of patients and were associated with advanced stage disease and with short time to first treatment and overall survival (80).

\section{Treatment}

CLL is the most frequently diagnosed leukemia in the Western world, yet it remains essentially incurable. Prognostic markers have evolved that help to predict the clinical course and to find high risk patients. Therapy of CLL has therefore significantly improved the past decade, resulting in prolonged survival.

In general newly diagnosed asymptomatic patients with early stage disease should be monitored without treatment and the standard approach for these patients is a watchand-wait strategy (86). Treatment of asymptomatic early stage disease patients with alkylating agents does not give any survival advantage $(55,87)$. When the disease start to progress the standard and most effective treatment is combination immunotherapy with fludarabine, cyclophosphamide and rituximab (FCR). This combination of purine analogue, alkylating agent and monoclonal CD20 Ab gives an overall response rate of about $90 \%(88,89)$. This treatment regimen can, however, be associated with high toxicity, which of course is a significant problem because most CLL patients are older. Other treatment options are therefore needed for the elderly. Patients with aggressive disease with poor prognostic markers such as del(17p) are resistant to fludarabine. Allogeneic hematopoietic stem cell transplant remains the only potentially curative treatment for patients with CLL, but is associated with high rates of treatment related mortality. This treatment should only be considered for young patients with poor prognosis (55).

Recent studies on treatment options have been focused on BcR signaling pathway inhibitors. The understanding of the importance of BcR signaling for CLL pathogenesis has opened up for the development of small molecule inhibitors of BcR-associated 
kinases, including spleen tyrosine kinase (SYK), bruton's tyrosine kinase (BTK) and phosphoinositide 3 kinase (PI3K). Inhibition of these kinases leads to redistribution of lymphoma cells from LN to PB and promote apoptosis of CLL cells in vitro $(90,91)$ Ibrutinib is a BTK-inhibitor, which blocks BcR signaling in vitro and in vivo. It impairs microenvironmental induced survival, proliferation migration and adhesion of CLL cells $(90,92-94)$. Ibrutinib is now approved by the FDA for use in CLL patients. Idelalisib is a PI3K-inhibitor, which as in analogy with Ibrutinib inhibits microenvironmental and BcR signals and reduce CLL cell survival and migration (95-97). Idelalisib was recently approved by the FDA for use in CLL.

\section{The CLL microenvironment and B cell signaling}

\section{Cellular microenvironment}

Several studies indicate that the microenvironment has a critical role in CLL cell survival and accumulation $(98,99)$. CLL cells circulating in the PB are most often arrested in the G0/G1 stage of the cell cycle but a small proportion of cells accumulate in structures termed pseudofollicles or proliferation centers (PC) in BM and LN, a hallmark finding of CLL histopathology (100). The microenvironment in PC constitute a tight 'cellular architecture' similar to that found in normal GCs of Ag-driven proliferation (Figure 3). These consist of mesenchymal stromal cells (MSCs) in the BM, monocyte derived nurselike cells (NLCs) and T cells in the LNs $(101,102)$. Microenvironmental interactions have been shown to be essential for inducing CLL cell survival and proliferation. In in vitro conditions CLL cells often undergo spontaneous apoptosis implying that in vitro cultured CLL cells lack essential survival signals that are present in the in vivo microenvironment. Unless CLL cells are cultured in the presence of other cell types or soluble cytokines and chemokines or other molecules that engage important cell surface receptors such as the $\mathrm{BcR}, \mathrm{CD} 38$, and CD40, they undergo apoptosis more rapidly than normal B lymphocytes (101-104). Historically, CLL was viewed as an accumulative disease of cells with a defect in apoptosis. Although the CLL cells in the blood are regarded as non-dividing, a small fraction of CLL cells replicate in PCs in BM and LNs. Recent studies using deuterated water labelling showed that the birth rate of the CLL cells varied from $0.1 \%$ to greater than $1 \%$ per clone and day and therefore was more pronounced than previously thought (105). 
The number of T cells is increased in CLL compared to healthy individuals (106). In PCs CLL cells interact with CD40-ligand (CD40L) expressing CD4+ $\mathrm{T}$ cells that bind to CD40 on CLL cells, rescuing them from apoptosis (107). CD40-cross-linking also up-regulates CD80 and CD54 on CLL cells which makes them effective T cell stimulators (108). The cross-talk between CLL cells and the accessory cells is bidirectional, causing interaction of both cell types. In the PCs CLL cells also interact with MSCs or NLCs. NLCs differentiate from blood monocytes, and can attract CLL cells and protect them from undergoing spontaneous or drug-induced apoptosis. NLCs can be found in the spleen and in the secondary lymphoid tissue of CLL patients. Gene expression patterns from CLL cells cocultured with NLCs and from CLL cells isolated directly from LN tissue are very similar with signs of $\mathrm{BcR}$ and nuclear factor (NF)- $\kappa \mathrm{B}$ activation and up-regulation of BcR-target genes such as CCL3 and CCL4 $(109,110)$. In addition, CLL cells also secrete these chemokines following BcR-stimulation or after co-culture with NLCs (109). NLCs secrete CXCL12 (stromal cell derived factor-1 [SDF-1]; ligand for CXCR4), CXCL13, B cell activating factor (BAFF), a proliferation inducing ligand (APRIL)(111) and express CD31 (ligand for CD38), plexin B1, and vimentin (112), which all are important molecules for NLC-CLL cross-talk supporting CLL cell survival, and are important therapeutic targets. Also FDCs are important for the support of CLL cells, partly dependent on ligation of CD44 on CLL cells and up-regulation of the anti-apoptotic protein myeloid cell leukemia 1 (MCL1) (113) as well as CD100/plexinB1 cross-talk (114). 


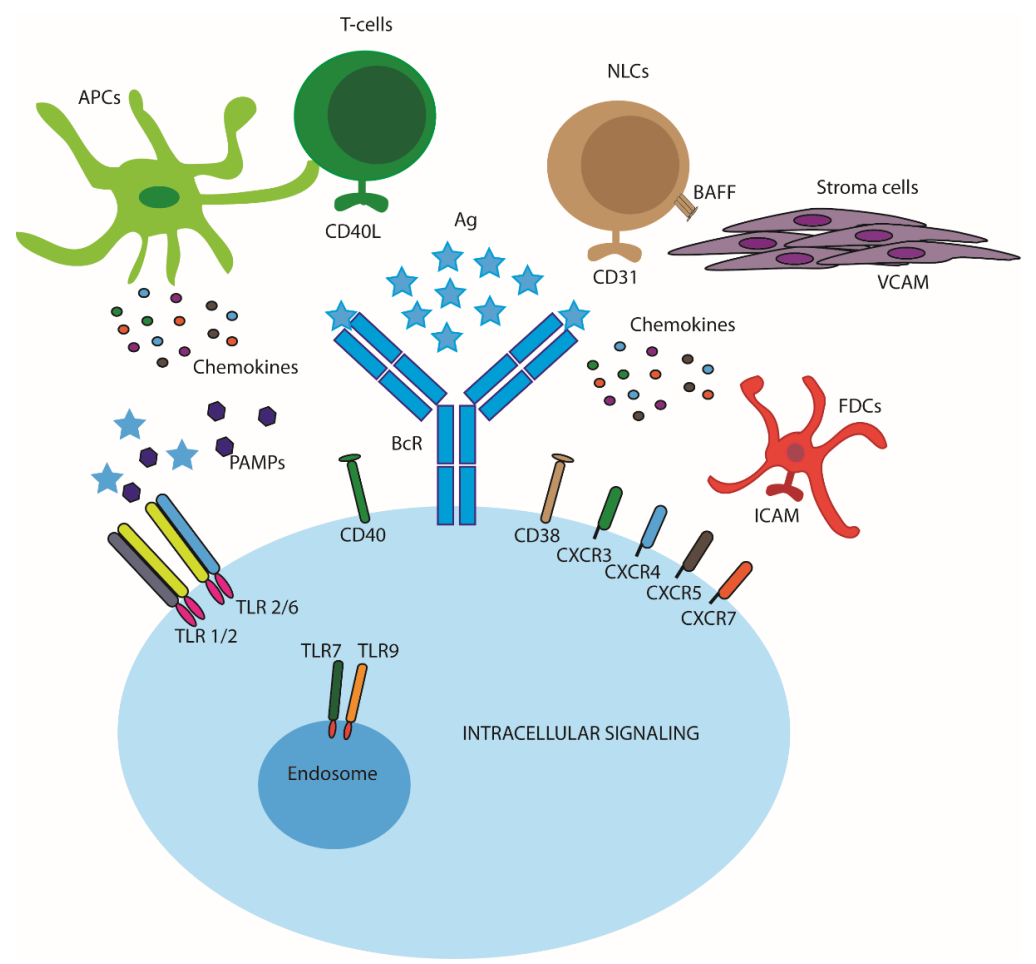

Figure 3. Interactions of CLL cells with their microenvironment

\section{The redox system}

ROS are products of normal metabolism and depending on concentration can be beneficial or harmful to cells and tissues. At physiological low levels ROS functions as signaling molecules in intracellular signaling and regulation, however excess ROS can induce oxidative modifications, inhibit protein function and promote cell death. Various pathologies, including cancer, can result from high oxidative stress (115). Therefore it is important that the cells have functioning reducing systems to maintain the redox balance. CLL cells suffer from a high level of ROS and oxidative stress, which renders them more dependent on the redox regulatory systems to maintain the redox balance $(116,117)$.

The three most important redox systems commonly found within the cells are: nicotinammide adenine dinucleotide phosphate $\left(N A D P H / N A D P^{+}\right)$, thioredoxin 
$\left(T R X_{\text {red }} / T R X_{o x}\right)$ and glutathione $(G S H / G S S G)$. In paper I in this thesis I have studied effects of Trx, therefore I will focus on the Trx system below.

Trxs are a family of proteins that have a conserved catalytic site (-Cys-Gly-Pro-Cys-) that undergoes reversible oxidation to the cystine disulfide (Trx-S2) through the transfer of electrons from the catalytic site cysteine residues (Cys) to a disulfide substrate (X-S2). The oxidized Trx is then reduced back to the Cys form [Trx-(SH)2] by the NADPHdependent flavoprotein Trx reductase (Figure 4) (118). Human Trx-1 is a small $12 \mathrm{kDa}$ protein. The central role of the Trx system is to provide a reducing environment and to protect the cell from effects of oxidative stress that ultimately leads to apoptosis. Trxs have been implicated in a number of mammalian cell functions and activity has been found outside the cell (cell growth stimulation and chemotaxis), in the cytoplasm (as an antioxidant and a reductant cofactor), in the nucleus (regulation of transcription factor activity), and in the mitochondria (119).

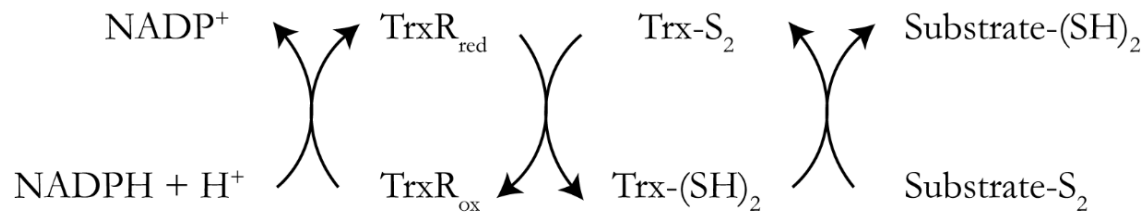

\section{Figure 4. Scheme of reactions catalyzed by the thioredoxin-dependent system}

Emerging evidence has shown that PTPs are highly susceptible to oxidation. The Cys residue in PTPs act as a redox sensor in response to proximal ROS. Oxidation of catalytic Cys residue results in enzymatically inactivated PTPs. The oxidized PTPs lose their enzymatic activity and are therefore incapable of dephosphorylating their substrates. In response to extracellular stimuli, which induce the production of active oxidants, PTPs are transiently inactivated allowing full activation of the protein tyrosine phosphorylation signaling cascade. Soon after the ROS burst is terminated, oxidized PTPs are converted back to the active state via GSH and other endogenous reductants, downregulating tyrosine phosphorylation signals. If the cellular redox potential is altered and the redox-balance is destroyed, it might lead to pathological consequences including carcinogenesis. In cancer cells that generate large amounts of ROS the active site Cys of 
PTPs might be constitutively oxidized, leading to uncontrolled tyrosine phosphorylation level.

A recent study reveal that BM stromal cells increase the ability of CLL cells to maintain the redox balance and promote cell survival and drug resistance by converting cystine to cysteine. Cysteine is then released into the microenvironment and CLL cells can in contrast to cystine take up cysteine and promote GSH synthesis which leads to increased CLL cell survival and drug resistance (120).

\section{BcR signaling}

The LN microenvironment is also an important site for BcR activation. BcR activation is most often induced by Ag, but can be ligand-independent (tonic), and triggers a downstream signaling cascade that cause B cell selection, proliferation, differentiation and $\mathrm{Ab}$ production (7). In CLL, BcR signaling plays a critical role in pathogenesis, however the mechanism of BcR stimulation are heterogenous and not yet fully understood. Gene expression studies demonstrate that BcR-signaling is the key regulatory pathway activated in CLL cells in LNs (110). Studies have revealed that cases with high levels of CD38, ZAP70, and carrying UM IGHV are more responsive to BcR-triggering than are cases with M IGHV genes (121). M CLL cells usually show a more anergic profile with constitutive phosphorylation of signaling proteins, including ERK kinase and reduced levels of responsiveness to BcR stimulation $(122,123)$. Recent clinical trials with agents that target the BcR signaling pathway, such as inhibitors of SYK, BTK, and PI3K $\delta$, are showing considerable activity in patients with CLL, further underscoring that the leukemic cells rely on BcR signals for growth and survival $(90,92,95)$.

Engagement of the BcR by $\mathrm{Ag}$ induces aggregation of $\mathrm{BcR}$ components that lead to phosphorylation of ITAMs in the cytoplasmic tails of Ig- $\alpha$ (CD79A) and Ig- $\beta$ (CD79B) by LYN kinase which in turn activates SYK, BTK and PI3K $\delta$ kinases and downstream pathways, including calcium mobilization, activation of phospholipase C (PLC) $\gamma$, protein kinase $\mathrm{C}(\mathrm{PKC}) \beta, \mathrm{NF}-\kappa \mathrm{B}$-signaling, mitogen activated protein (MAP) kinases, and nuclear transcription (Figure 5). Collectively, these signaling events promote B cell survival and proliferation. The intensity and duration of the BcR signal are controlled, modulated and fine-tuned by various positive (CD19) and negative regulatory co-receptors and phosphatases. Phosphorylation of the inhibitory receptors CD22, Fc $\beta$ RIIb, CD5 and CD72 
brings the phosphatases SHP-1 and SHIP-1 in the vicinity of the Ag-stimulated BcR and inhibit the signal by dephosphorylating activated components of the BcR-signaling pathway $(124,125)$. Importantly, some of these negative regulators are also activated by LYN, which functions as both a positive and negative regulator of BcR-signaling. Several molecules involved in BcR signal transduction, such as LYN, SYK, PIK3, and PKC are constitutively active in CLL (126-129).

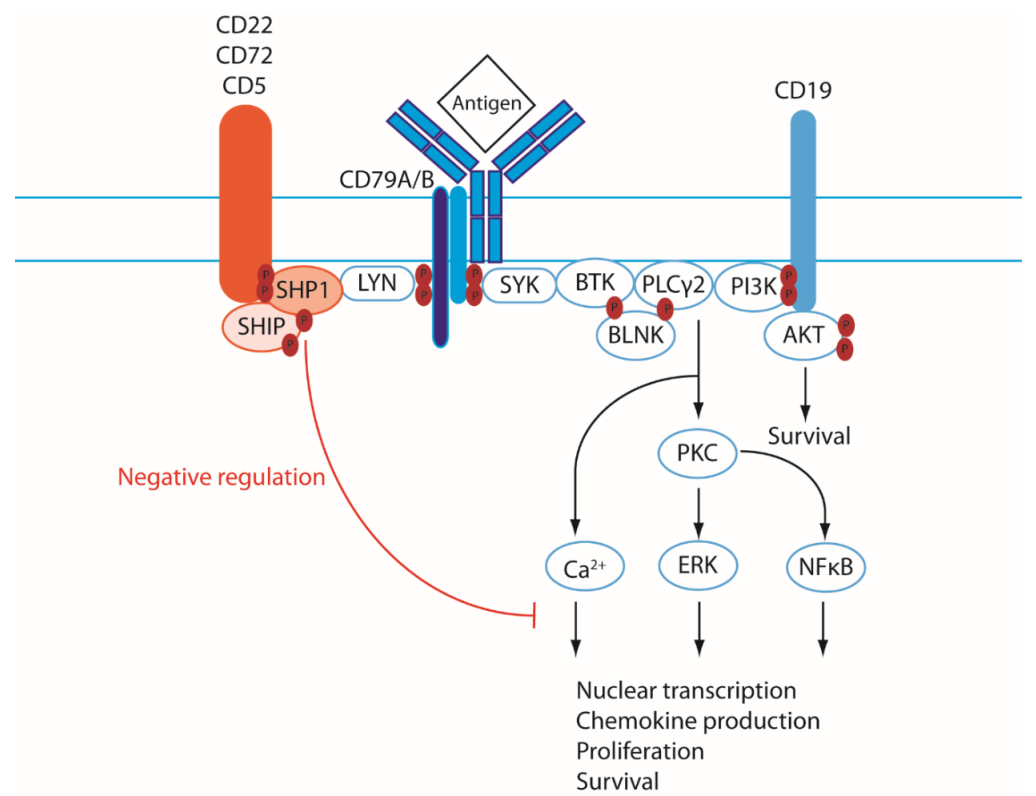

Figure 5. B cell receptor signaling

\section{TLRs}

Other key molecules such as TLRs have been shown to act concomitantly with the BcR and to have a role in CLL development and progression (130). TLRs are part of the innate immune system and trigger an immediate immune response upon engagement. TLRs can act to bridge innate and adaptive immunity by acting as co-stimulatory signals for B cells and induce maturation, proliferation and Ab secretion (131). TLR7 and TLR9 can together with the BcR participate in responses to autoantigens. Expression of TLRs in CLL $\mathrm{B}$ cells are similar to that of B cells from tonsil and memory B cells and express functional TLR1, TLR2, TLR6, TLR7, TLR9 and TLR10 (132-134). Subgroups of CLL cases, especially 
those belonging to subsets with stereotyped BcRs, show differential responses to immune stimulation through the TLRs, and these responses may extend to cell proliferation control, apoptosis, B-cell anergy, or TLR tolerance (130).

\section{Stereotyped B cell receptors in CLL}

CLL was previously thought of as a homogenous disease derived from naïve, Aginexperienced B cells. This view has over the past decade changed dramatically. Findings from immunogenetic studies that CLL patients can be subdivided into two groups with different prognosis depending on the mutational status of the rearranged IGHV genes (59, 60) started an interest among researchers for IG genes and the involvement of Ag in the disease pathogenesis. Today, it is well known and accepted that IGHV and IGLV gene usage in CLL B cells is highly biased and non-random showing preference for certain IGHV genes such as IGHV1-69, IGHV3-7, IGHV3-21 and IGHV4-34 $(135,136)$. Perhaps the strongest evidence for Ag involvement is the existence of different subsets of cases with highly restricted or "stereotyped" VH CDR3 sequences, characterized by shared amino acid motifs. This suggests that clones with stereotyped BcRs, recognize similar antigenic epitopes. There are today more than 200 subsets of patients that express such stereotyped BcRs $(1,135,137,138)$. More recent studies based on large amount of sequences collected from different countries, and with the development of new bioinformatics tools, reveal that stereotopy is more common amongst UM CLL than M CLL. Phylogenetically related IGHV genes can be members of the same group, and groups of patients share clinical and biological features such as for example genomic aberrations, epigenetic modifications and cell-signaling via innate and/or adaptive signaling pathways $(2,3,139,140)$. For example, subsets \#1 (IGHV1/5/7/IGKV1-39), \#2 (IGHV321/IGLV3-21) and \#4 (IGHV4-34/IGKV2-30) have different clinical outcomes, with indolent disease in subset \#4 and aggressive disease in subset \#1 and subset \#2 (141).

\section{Antigens in CLL}

The observations, as mentioned above, that a large number of CLL patients share stereotypic BcRs/mAbs suggests recognition of similar antigenic epitopes and a role for Ags in the disease onset and/or development. Early studies have shown that CLL Abs are polyreactive and recognize autoantigens such as single stranded DNA (ssDNA), double 
stranded DNA (dsDNA), histones, cardiolipin or cytoskeletal components (142, 143). Along with the findings of stereotyped receptors in CLL and the development of new techniques to produce recombinant Abs the interest to search for Ag specificity took off again. The results that emerged from these studies revealed that only the UM CLL Abs had an auto- and polyreactive nature whereas the M CLL Abs had lost this ability due to SHM. Studies also showed that M CLL patient IGs regained their polyractivity when reverted back to its germline configuration, indicating that both UM and M CLL B cells derive from self-reactive precursors (144). Interestingly, the combined message from several studies regarding CLL IG specificity is that CLL Abs bind to molecular epitopes on apoptotic cells and that CLL Abs assigned to the same subset exhibit similar Ag-reactivity profiles. More specifically, CLL mAbs have been found to bind to vimentin, filamin B, cofilin-1, prolinerich acidic protein 1 (PRAP-1), phosphorylcholine, cardiolipin, non-muscle myosin heavy chain IIA (MYHIIA), and metabolites of lipid peroxidation all of which are exposed on the cell surface upon apoptosis (145-147). Not only self but also microbial, viral and fungal Ags have been recognized as targets of CLL BcRs (148). The same oxidized epitopes found on apoptotic cells are also exposed on some bacteria ie Streptococcus pnemoniae and on oxidized low density lipoprotein (oxLDL) (145). Viral infections have also been suggested to drive the CLL clone. For instance infections by Epstein-Barr virus or Cytomegalovirus have been associated with subset \#4 (149). Autonomous signaling have also been described in CLL, where CLL derived Igs induce Ag-independent cell-autonomous signaling due to self-recognition of an intrinsic IGHV motif (150). However, the relevance of these interactions still remains unclear. A combination of signals generated by cell autonomous $\mathrm{BcR}$ interactions and interactions with external low-affinity autoantigens could be important to modulate the disease and to provide important co-stimulatory signals (151).

\section{Origin of $C L L$}

The transformation events that select normal B cells to become CLL B cells remain at present unknown. The cellular origin of CLL cells has been an area of considerable debate. It has been proposed that CLL cells derive from B1-like cells, MZ B cells or transitional B cells, based on cell surface phenotype and molecular and functional characteristics. 
For about two decades ago CLL was thought off as an accumulative disease with cells originating from naïve non-proliferating immune incompetent cells. Later studies showed that CLL could be divided into subgroups with CLL clones using either M or UM IGHV genes which showed different clinical outcomes $(59,60)$. These observations gave rise to the hypothesis that the different subgroups originated from distinct cell types. UM CLL cells were to derive from naïve $\mathrm{CD}^{+}$pre-GC B cells and the M CLL cells from a CD5 ${ }^{+}$ memory cell. This model have since been modified, since both subsets have been shown to express surface markers and gene expression profiles of activated, Ag-experienced cells. Furthermore, gene expression studies showed similarities to memory B cells and also revealed very few differences between the two subsets, suggesting a single precursor (152). However, the definition "Ag-experienced" do not need to be restricted to mature B cells reacting with foreign Ags but can apply to any cell regardless of maturation status, after the expression of a rearranged IGH.

Today, we know that CLL cells produce Abs with binding specificities resembling natural Abs. CLL BcRs are often skewed toward polyreactivity with binding to autoantigens as well as exoantigens. There are at present three different cell subsets discussed to be the CLL cell counterpart, the MZ B cell, the B1 cell and the transitional B cell. The MZ B cell shares many CLL cell features. MZ B cells can display an activated phenotype after Ag encounter. They express BcRs which is coded by UM and M IGV genes, which are polyreactive and can bind autoantigens as well as microbes. However, the MZ B cell has a different surface phenotype than CLL cells, in that they are CD5-CD23-CD22+ (45). This difference in phenotype however could reflect activation status. The B1 cells produce germline encoded, polyreactive, autoreactive natural Abs, which serve as a part of the innate immune system to protect against microbes and to eliminate catabolic debris (153). Furthermore, it has been shown that B1 cells can give rise to a CLL like disease in aging mice (154). What contradicts B1 cells as CLL origin is the lack of a truly identified human counterpart and that they almost exclusively express UM IGHV genes (153). Transitional B cells express CD5, can be autoreactive and express both $M$ and UM IGVs $(155,156)$. Findings against transitional B cells as CLL origin are expression of CD10 not present on CLL cells, absence of CD27 expressed on CLL cells and lack of responsiveness to BAFF which effectively supports CLL cell survival (156). 
With the evidence for stereotyped receptors in some but not all CLL clones, the concept of a single cell origin of CLL is being challenged. Leukemogenesis in CLL may follow a long stepwise process, where transforming events can occur at any time during B cell maturation. Thus, it is possible that CLL can be derived from multiple CLL precursors (157).

\section{DNA methylation}

The current definition of epigenetics is "the study of heritable changes in gene expression that occur independent of changes in the primary DNA sequence". Epigenetic modifications include methylation of cytosine bases in DNA, post-translational modifications of histone proteins as well as the positioning of nucleosomes along the DNA. Not all genes are active at all times. DNA methylation is one of several epigenetic mechanisms that cells use to control gene expression. Methylation of DNA is a common epigenetic signaling-tool that cells use to lock genes in an off-position. Proper DNA methylation is essential for cell differentiation and embryonic development. DNA methylation in mammals primarily occurs by the covalent modification of cytosine residues in CpG dinucleotides of DNA which are converted to 5-methylcytosine by DNA methyltransferase (DNMT) enzymes. The altered cytosine residues are usually immediately adjacent to a guanine nucleotide, resulting in two methylated cytosine residues sitting diagonally to each other on opposing DNA strands. In mammals CpG dinucleotides are concentrated in GC rich regions where high CpG contents are found, these regions are called CpG-islands. CpG islands are positioned in the 5' end of many human genes and occupy $\sim 60 \%$ of human gene promoters. The majority of $\mathrm{CpG}$ islands remain unmethylated during development and differentiation allowing gene expression to occur. In contrast most of the CpG sites scattered in the genome are methylated (158160). Given the critical role of DNA methylation in gene expression and cell differentiation, failure of the proper maintenance of epigenetic marks can result in inappropriate activation or inhibition of various signaling pathways and lead to disease states such as cancer.

\section{DNA methylation in tumorigenesis}

Normal cells have genes that promote cell proliferation (oncogenes) and those that suppress cell proliferation (tumor suppressor genes). Mutations of oncogenes can result 
in constitutive activation of these genes. In contrast mutations and/or chromosomal deletions of suppressor genes result in their inactivation. Oncogene activation and tumorsuppressor gene inactivation can lead to uncontrolled cell proliferation and development of cancer. Recent research have shown that not only mutations and/or deletions of certain genes but also aberrant DNA methylation contribute to cancer pathogenesis. 3$6 \%$ of all cytosines are methylated in normal human DNA. Methylable CpG dinucleotides are not randomly distributed in the human genome but instead $\mathrm{CpG}$-rich regions known as CpG islands, which span the $5^{\prime}$ end region of many genes, are usually unmethylated in normal cells. In cancer cells, the CpG-island promoter of some tumor-suppressor genes are hypermethylated and therefore silenced (Figure 6). DNA methylation is regarded as a relatively stable modification and is now considered one of the hallmark mechanisms of aberrant gene silencing in cancer.

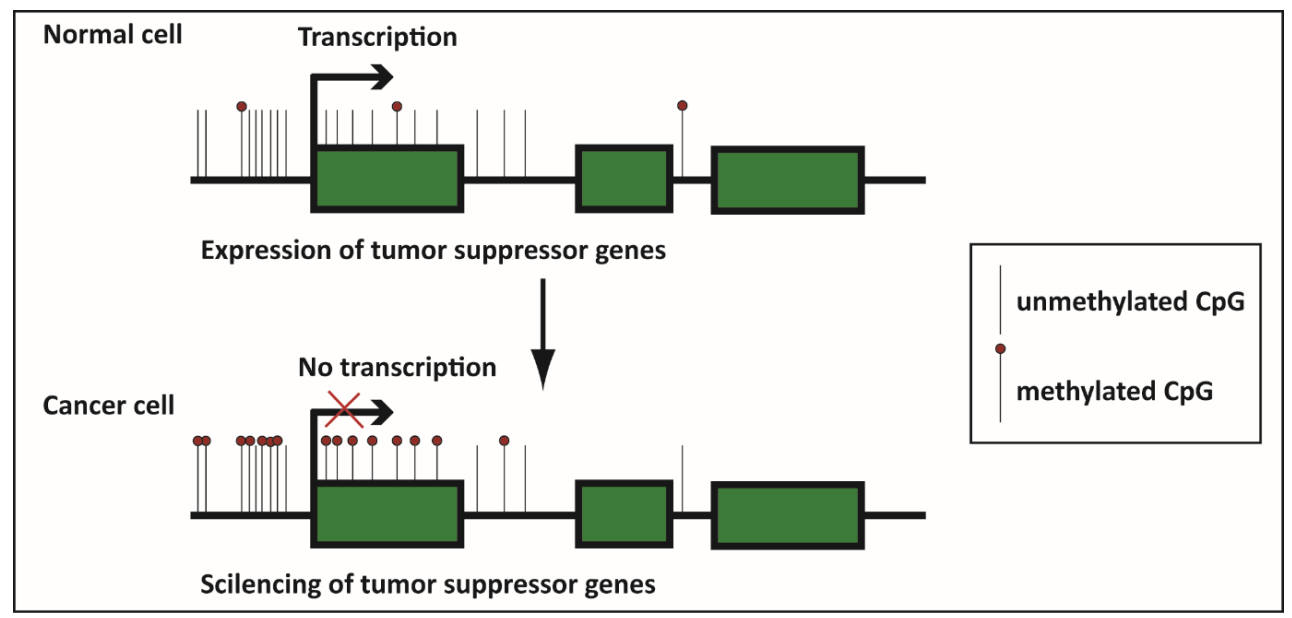

Figure 6. DNA methylation in normal and cancer cells

\section{Role of DNA methylation in CLL}

Aberrant DNA-methylation has over the past two decades evolved as a key player in the pathogenesis of CLL. Early studies of DNA methylation revealed the importance of hypermethylation as a key event promoting genomic instability and oncogene activation in CLL and other cancers. Later studies revealed DNA from CLL patients to be globally hypomethylated compared to PB cells from normal healthy individuals (161) which is true also for other cancers. In the early days of epigenetics, methylation patterns were determined in single genes. In this way, several gene promoters have been shown to be 
hypermethylated and some of these can also be coupled to disease progression and survival. DNA methylation of TWIST2, a transcription factor and known silencer of p53, has shown to be more frequent within IGHV M CLL patients, (162) similarly silencing of HOXA-4 (163), transcription factor important for cell development, and ZAP70 (164) through DNA methylation also correlated to IGHV mutational status. With the development of new more global, high-resolution microarray and sequencing technologies, it became possible to determine DNA methylation on a global level. Kanduri $\mathrm{M}$ et al demonstrated a differential methylation pattern distinguishing poor prognostic IGHV UM from favorable prognostic IGHV M CLL patients. Several tumor suppressor genes were shown to be methylated in UM cases. Furthermore, genes involved in cell signaling such as MAPK and NF- $\mathrm{KB}$ were shown to be unmethylated in UM cases (165). Comparison of methylation profiles of three distinct stereotyped subsets with different prognosis; subset \#1 and \#2 (poor-prognosis) and subset \#4 (favorable prognosis), revealed significantly different methylation profiles. Interestingly the majority of the differentially methylated genes were involved in B cell activation. Furthermore, these genes were found to be more methylated in subset\#1 than in subset\#2 and \#4 (166). Recently it was shown that M CLL and UM CLL maintain an epigenetic signature of memory B cells and naïve B cells, respectively (167). Later the same group showed that this epigenetic classification was a strong predictor of time to first treatment along with Binet stage (168). In recent years dysregulation of miRNAs have been demonstrated (166) in CLL, which has an effect on the expression of tumor suppressor and oncogenes (169-171). The mechanisms underlying altered miRNA expression are poorly known but could be due to epigenetic manipulation. Bear et al. have by integrating DNA methylation and miRNA promoter data identified 128 recurrent miRNA targets for aberrant promoter DNA methylation in CLL (172).

\section{Epigenetic based treatment}

Since epigenetic modifications do not involve changes in the DNA sequence, the change is reversible. Methylated genes can be re-expressed after treatment with DNA methyltransferase inhibitors. The only approved DNA methylation inhibitor present is 5' Azacytidine and is used for patients with myeloplastic syndrome only (173). 
The overall aim of this thesis was to study the influence of the microenvironment on the B cells of both peripheral blood cells and cells from lymph nodes. The specific aims were as follows:

\section{Paper I}

- To study the production of thioredoixn from the microenvironmental cells in the CLL LN compartment.

- To access the influence of thioredoxin on CLL cell viablility.

\section{Paper II}

- To study the binding of CLL subset \#1 Abs to native antigen malondialdehyde modified low density lipoprotein (MDA-LDL)

- To evaluate the effect of antigen binding to CLL cell BcR on cell activation and/or proliferation.

\section{Paper III}

- To study DNA methylation profiling of different prognostic subgroups.

- To evaluate changes in the global DNA methylation profiles of CLL patients over time and in patient-matched LN and PB samples.

\section{Paper IV}

- To study SHP-1 expression and activity in CLL patients using matched LN and PB samples. 
Since detailed description of methods used is written in the material and methods section in each paper, I will only present the patient material below.

\section{Patient samples and patient characteristics}

Primary CLL cells from patient PB and/or LNs were used in Paper I-IV.

In Paper I, LNs from 13 CLL patients and PB from five CLL patients were collected from consecutively attending patients at the Hematology Clinic at Linköping University Hospital. In addition, LN sections from 12 CLL patients were collected at the Department of Pathology at Uppsala University Hospital.

In Paper II, PB samples from 12 CLL patients belonging to the stereotyped subset \#1 (Clan I IGHV/IGKV1(D)-39) were collected, six patients from Papanicolaou Hospital, Thessaloniki, Greece, four patients from Rigshospitalet, Copenhagen, Denmark and two patients from Uppsala University Hospital.

In Paper III, a total of 36 PB samples were obtained from the Swedish part of the SCALE study. For DNA-methylation studies sorted PB samples from 9 IGHV mutated and 9 IGHV unmutated cases were analyzed. PB samples from these same patients were also collected at later time-points for DNA-methylation analysis over time. In addition, 10 patientmatched PB and LN samples were collected from Linköping University and Uppsala University hospitals. PB from three age-matched normal individuals and one wholegenome amplified DNA derived from PB were included as controls.

In Paper IV, LNs and matched PB samples were collected from 6 CLL patients. Five patients from Linköping University Hospital and one patient from Uppsala University Hospital. In addition PB was collected from 14 CLL patients from Linköping university Hospital. 
All samples were diagnosed according to the WHO classification and the international Workshop on Chronic Lymphocytic Leukemia criteria (IWCLL) (55). In Paper I all samples were analyzed unsorted. In Paper II some samples were negatively selected for CD19+/CD5 ${ }^{+}$cells before experimentally used and some were used unsorted as detailed in the paper. In Paper III and IV all samples were CD19+/CD5 ${ }^{+}$sorted. Patient characteristics are outlined in each paper. Informed consent was obtained according to the Declaration of Helsinki.

\section{Ig gene sequencing}

In Papers I-IV IG gene sequencing was performed by PCR amplification of DNA using IGHV gene specific primers. The PCR products were sequenced and aligned against germline sequences in the IMGT® database using the IMGT/V-QUEST online tool (http://www.imgt.org) (174). Samples with less than 98\% homology to the germline IGHV sequences were considered as mutated. Patients were assigned to different stereotypic subsets following recently established criteria

\section{Cell purification}

Peripheral blood mononuclear cells (PBMCs) were isolated by Ficoll-gradient centrifugation (GE Healthcare) and were negatively selected using magnetic beads specifically developed for CLL cell purification (MACS microbeads, Miltenyi Biotec) when indicated. The $\mathrm{CD}^{+} / \mathrm{CD} 19^{+}$cells were $>97 \%$ as assessed by flow cytometry.

Stromal cells including FRC and FDC were purified from CLL lymph nodes and tonsil tissue. Single cell suspensions were retrieved after mincing the lymph nodes and tonsils in a stainless steel mesh. The cells were seeded in tissue flasks and adherent cells were fed every fourth day by replacing $50 \%$ of the medium until confluence. Phenotype of the adherent cells was analyzed by flow cytometry. 


\section{Thioredoxin produced by stromal cells influence CLL cell survival (Paper I)}

The CLL BM and LN microenvironment has been shown to be essential in several ways for CLL cell survival and proliferation. CLL cells undergo spontaneous apoptosis when cultured in vitro which implies that they lack essential growth factors present in the in vivo microenvironment. In this paper, we wanted to further elucidate important growthpromoting interactions and focused on the Trx system. Trx is a small redox-active and multifunctional molecule expressed at low amount in all cells in the body, containing an active site motif with amino acid Cys-X-X-Cys (118) that undergoes reversible NADPHdependent reduction by selenocysteine containing flavoprotein Trx reductases. It is a potent antioxidant and protein disulfide oxidoreductase. Intracellular Trx has antiapoptotic as well as growth-promoting effects and additionally, some types of cells have the capacity to release Trx where the extracellular form of Trx has cytokine and chemokine activities (175). Interestingly, exogenous Trx was previously shown to protect malignant CLL cells from apoptosis in vitro (176). In paper I, we analyzed the expression of Trx in vivo in frozen sections from CLL LNs, and in vitro by culturing the Trx expressing cells. Furthermore, we analyzed the effect of secreted Trx on CLL B cells.

In this study, we found Trx in CLL LNs to be highly expressed in cells with macrophageand/or fibroblast/dendritic-like morphology (Figure 7), the tumor cells themselves however expressed very low levels. The Trx expressing cells were identified as FDCs and follicular reticular cells (FRCs). Expression of Trx correlated with the presence of stromal cells and proliferating Ki-67+ leukemic cells and the Trx expressing cells were mainly localized to and surrounded by Ki-67+ leukemia cells, indicating that Trx is a potential tumor survival factor. Furthermore, these stromal cells were able to spontaneously secrete Trx ex vivo. Co-culturing of stromal cells with CLL B cells extended B cell survival, which could be blocked by a neutralizing Trx Ab (Figure 8), indicating that stromal derived Trx is a pro-survival factor for CLL B cells. 

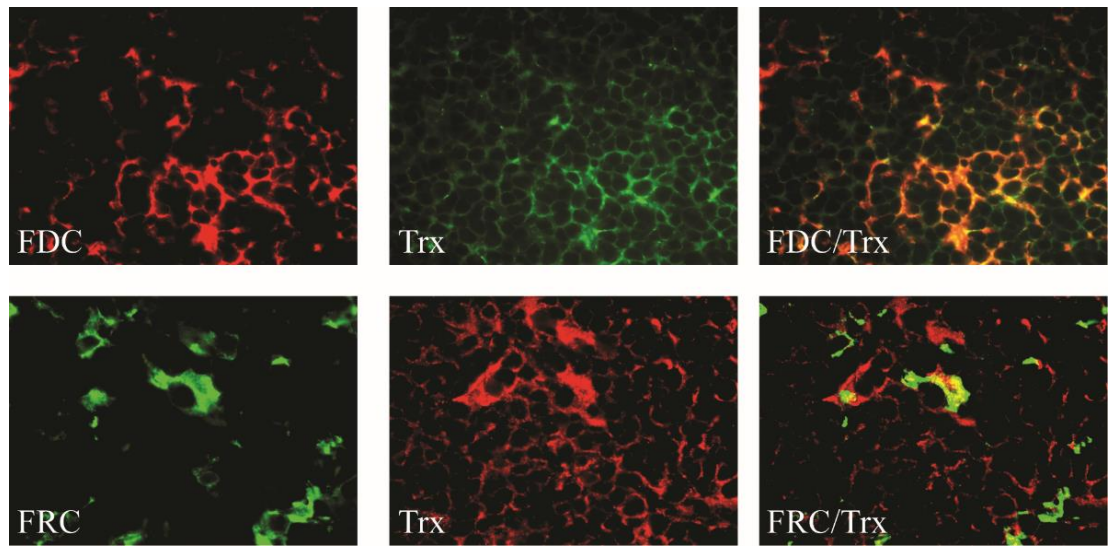

\section{Figure 7. In vivo expression of thioredoxin}

Stromal cells (FDCs; Follicular dendritic cells and FRCs; Follicular reticular cells)

overexpress thioredoxin. Frozen lymph node sections were stained with antibodies for FDC or FRC together with anti-Trx (2G11).

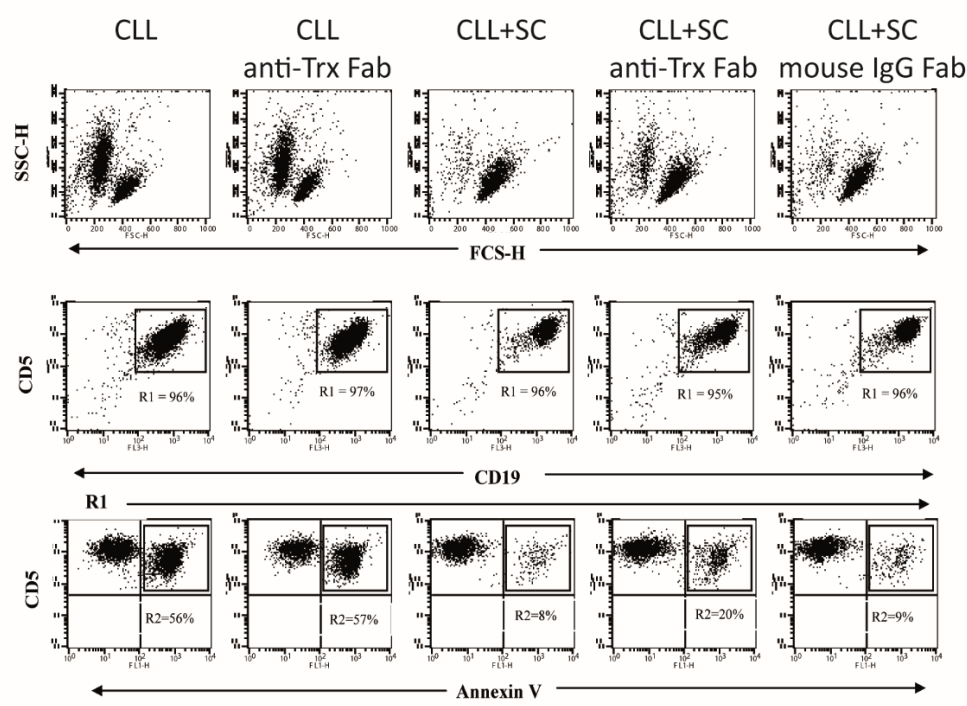

Figure 8. Thioredoxin-mediated improvement of leukemic cell survival after coculturing with stromal cells from CLL lymph nodes.

Leukemia cells from the blood of CLL patients were cultured with and without stromal cells purified from tonsils or CLL lymph nodes in the presence or absence of anti-thioredoxin Fab fragments 
The detailed molecular mechanism behind the improved Trx-mediated CLL survival remains to be elucidated. However, it is known that the multifunctional Trx protein exerts several redox-regulatory functions and physically associates with a large number of target proteins, modulating their three-dimensional structure (and functions) by catalyzing thiol-disulfide exchange reactions. Trx, through its redox activity, regulates the activity of enzymes such as apoptosis signal-regulating kinase 1 (ASK-1) (177) and PKC $\alpha, \gamma, \varepsilon$, and $\delta(178)$ and either directly or indirectly modulate the DNA binding activity of transcription factors, including NF- $\mathrm{kB}$ (179), the glucocorticoid receptor (180), p53 (181) redox protein redox factor-1 (Ref-1) (182) and activator protein-1 (AP-1) (183), thus affecting various aspects of cellular responses including redox homeostasis, cell growth, and survival. Trx is a key protein in inducing synthesis of several cytokines, including IL4, interferon- $\gamma$, and TNF- $\alpha$, which are known to exert survival effects on CLL cells (184). Recently it was demonstrated that Trx catalytically interacts with a single principal target protein on the surface of lymphocytes. This target protein was identified as the TNF receptor superfamily member 8 (TNFRSF8) also known as CD30 (185). CD30 is a receptor of activated lymphocytes involved in the regulation of inflammation (186). Trx catalyzes disulfide exchange dynamically, activating or inactivating the CD30 pathway in response to the redox environment, thus affecting lymphocyte effector functions (185). Furthermore, we have shown (see paper III) that TNFRSF8 is differentially methylated in IGHV M and IGHV UM CLL cases.

Trx expression is increased in several human primary cancers, including lung, colon, cervix, liver, pancreatic, colorectal, and squamous cell cancer (118). In contrast to other cancers where Trx has been shown to be overexpressed in the tumor cells per se, we found Trx to be minimal expressed in CLL cells but overexpressed in the accessory cells surrounding the leukemic cells. However despite the source, Trx seem to be linked to aggressive tumor growth and inhibition of apoptosis (187). Recently, in line with our results, Li et al found Trx to be highly expressed in diffuse large B cell lymphoma (DLBCL), not only in the tumor cells but also in stromal cells in the surrounding microenvironment (188). A recent study show that transfection of human MCF-7 breast cancer, human HT29 colon cancer and mouse WEHI7.2 lymphoma cell lines with Trx-1 have increased levels of HIF-1 $\alpha$ protein during both normoxic and hypoxic conditions, which promote angiogenesis (189). This may provide a mechanism to explain the aggressive tumor 
growth observed in tumors overexpressing Trx. Inhibitors targeting Trx pathway provide a promising therapeutic strategy for cancer prevention and intervention (190-192), however no such studies have been performed in CLL.

\section{Chronic autoantigen-BcR engagement induce un- responsiveness/anergy in subset \# 1 CLL (Paper II)}

Several lines of evidence suggest that the development and evolution of CLL is dependent upon the interplay between genetic defects and stimuli originating from the microenvironment, including important cellular components and soluble factors as well as antigenic stimulation through the BcR. Molecular and functional studies support the concept that CLL cells are Ag-experienced, where the strongest evidence for Ag involvement is the existence of different subsets of cases with highly similar or "stereotyped" IGs in their BcRs, indicating selection by Ag in CLL ontogeny $(193,194)$. Within stereotyped subsets, similarities between different cases extend from BcR IG sequences to biological and prognostic features, clinical presentation and even outcome (2, 193-195).

Studies by our group, confirmed by others, showed that CLL Abs may recognise oxidationspecific neo-epitopes on lipoproteins and apoptotic cells. Interestingly, these structures may also share molecular identity with epitopes on infectious pathogens so called molecular mimicry $(145,147,196,197)$.

Stereotyped subset \#1 is the largest subset among the IGHV UM CLL with frequencies about 2.5\%-3\% $(2,3,140,198)$. We recently found that IgM from subset \#1 CLL cells bind to oxidized phospholipids (145), more specifically to malondialdehyde (MDA). MDA is a major degradation product of unsaturated lipids reacting with reactive oxygen species. Although there is no doubt that $\mathrm{Ag}-\mathrm{BcR}$ interaction is of great importance in the pathogenesis of CLL this interaction has not been studied with cognate Ag. The discovery of subset \#1 cognate Ag enabled us to study the contribution of antigen in triggering proliferation and/or differentiation of CLL cells.

In paper II, we hypothesized that the cognate multivalent Ag oxLDL could induce a full proliferative response on its own in this poor-prognostic subset. However, in contrast to 
our expectation, although subset \#1 Abs were shown to bind specifically to oxLDL (Figure 9), by analyzing BcR-signaling events we found that oxLDL alone was not sufficient for induction of $\mathrm{Ca}^{2+}$-flux, proliferation, or IgM secretion, indicating a state of $\mathrm{BcR}$ unresponsiveness/molecular anergy including constitutive ERK1/2-phosphorylation. Interestingly, this unresponsiveness could be relaxed after $48 \mathrm{~h}$ in culture (Figure 10).

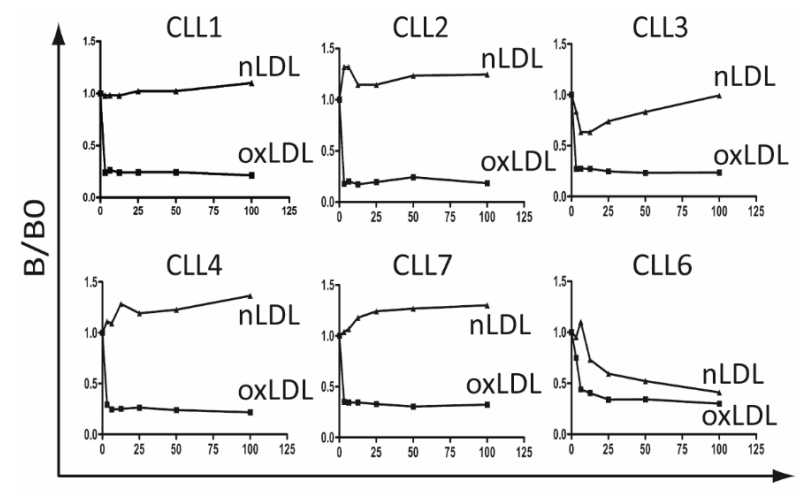

[Competitor] $\mu \mathrm{g} / \mathrm{mL}$

\section{Figure 9. Subset \#1 CLL IgM antibodies bind specifically to oxLDL}

Specificity of secreted subset \#1 CLL IgM Abs tested in competition ELISA. B/Bo indicates ratio of IgM bound in the presence of competitor (oxLDL or $n L D L$ ) divided by IgM bound without competitor.

$\mathbf{T}_{\mathbf{0 h}}$

A

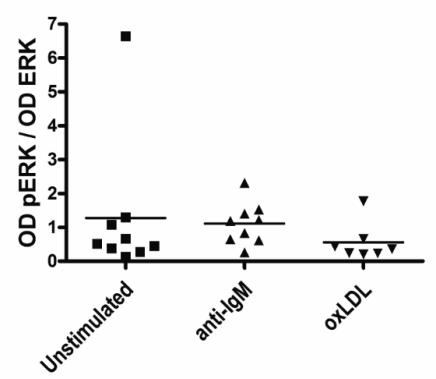

$\mathrm{T}_{48 \mathrm{~h}}$

B

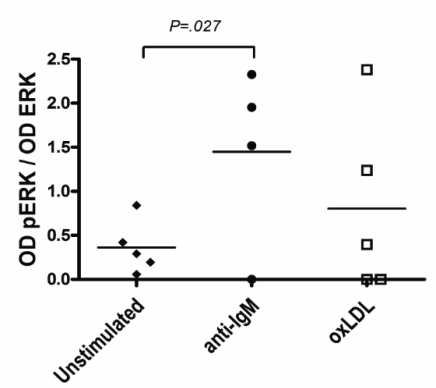

Figure 10. BcR responsiveness at start $(0 \mathrm{~h})$ and after $48 \mathrm{~h}$ of in vitro culture.

(A). Subset \#1 CLL cells were analyzed for phosphorylation of ERK1/2 by Western blot analysis at basal level (TOh), and (B) after 48-h in vitro culture (T48h) in the presence or absence of the indicated stimuli for $5 \mathrm{~min}$ 
It has been assumed for many years that CLL cells are anergic since they have very low surface expression of IgM and do not respond properly to BcR stimulation. BcR unresponsiveness in a context of B cell anergy is brought about by a condition in which self-reactive B cells are silenced upon chronic exposure to low-affinity autoantigens in vivo. Anergized B cells are characterized by $\operatorname{low} \operatorname{sIgM}$, as a result of constant BcR internalization and recycling, elevated basal intracellular $\mathrm{Ca}^{2+}$ concentration, and subsequent constitutive activation of ERK1/2 (28). Previous studies have shown that CLL cells are heterogeneous in their ability to respond to stimulation via the BcR (122). UM CLL cases preferentially respond to cross-linking with anti-IgM, exhibiting prominent $\mathrm{Ca}^{2+}$ mobilization and phosphorylation of intracellular kinases, whereas M CLL cases usually are more unresponsive and therefore regarded as being more anergized. Anergy appears to be isotype specific since cases that fail to signal via surface IgM are capable of signaling via surface IgD. Observations that expression of surface IgM and the ability to signal upon its engagement, could be recovered by incubation in vitro, strongly suggests that Ag engagement occurs in vivo and that the cells partly recover when they circulate in the blood $(122,123,199)$.

Not only the BcR but also several other molecules/receptors are important for the B cells to sense their microenvironment, including CD40, TLRs, BAFF and APRIL. Evidence is increasing that membrane associated as well as endosomal TLRs have a role in CLL development and progression $(130,200)$. TLR-stimulation provides a signal that synergizes with BcR-triggering and T cell help to amplify human B cell responses to Ag (201). Hence, stimulation with TLR-agonists increases the expression of co-stimulatory molecules, which in turn raise the surface expression of activation markers such as CD25 and CD86 $(123,133,202)$. Furthermore, functional interactions between the BcR and TLR signaling pathways are implicated in the control of B cell anergy. As recently shown, subgroups of CLL cases, especially those belonging to subsets with stereotyped BcRs, exhibit differential responses to immune stimulation through the TLRs, and these responses may extend to cell proliferation control, apoptosis, B cell anergy, or TLR tolerance (130). The state of paralysis may be recovered by exogenous or endogenous factors breaching the unresponsiveness and this is relevant for understanding CLL clonal dynamics. Indeed, co-signals from exogenous microbes or, alternatively, aberrant signals via endogenous innate receptors such as NOTCH1 may circumvent normal controls. TLR- 
signaling has been reported to breach B cell anergy (28) as was also the case in roughly half of the CLL cases of the present study. Most likely, therefore, a combination of several signals (including environmental/microbial TLR-ligands) are required to surpass a critical threshold for allowing S-phase entry in these CLL cells.

\section{DNA methylation patterns: a comparison between resting and proliferative compartment as well as over time (Paper III)}

Recently, using 27K DNA methylation microarrays, Kanduri et al recognized differential methylation pattern for IGHV UM and IGHV M CLL patients (165). They found a number of proliferation related genes to be unmethylated in the IGHV UM subgroup of patients. In paper III, we wanted to study DNA methylation pattern in CLL on a larger scale, utilizing 450K global arrays. More specifically, we sought to determine DNA methylation changes over time and to search for changes attributed to alternative microenvironments, i.e. resting and proliferative compartments. A total of $2239 \mathrm{CpG}$ sites were found to be differentially methylated between IGHV M and U CLL, with the majority of sites outside of known annotated CpG islands and within gene bodies, in line with the recent findings by Kulis et al (167).

Ontology analysis of 1826 differentially methylated genes identified a number of enriched physiological and molecular functionalities, most of which has not been implicated in CLL, however many of the identified genes were members of recognized signaling pathways and also genes shown to be involved in other cancers.

A more focused search for genes implicated in CLL revealed differential methylation of known CLL prognostication genes (summarized in Table 3), such as ZAP70, LPL and CLLU1. We found ZAP70 to be preferentially methylated in IGHV M cases compared to IGHV UM cases, this is in line with results from Corcoran et al. (164). Recent studies have shown that methylation of ZAP70 correlates well to ZAP70 expression (164). For the first time, the CLL prognostic genes $L P L$ and $C L L U 1$, were found to be epigenetically regulated. Gene expression of $L P L$ and CLLU1 has been shown to be higher in IGHV UM patients compared to IGHV M cases Accordingly, higher DNA methylation of the CLLU1 gene was 
present in IGHV M CLL compared with IGHV UM cases. Also higher DNA methylation of the LPL gene was found in IGHV M compared to IGHV UM cases (203-205). Interestingly, we found NOTCH1 to be higher methylated in IGHV M than IGHV UM subsets. NOTCH1 has been identified as mutated gene in CLL and a predictor of poor survival (76). Furthermore, we found differentially methylated genes related to apoptosis (LEF-1 (206) and TCF3 (207)), proliferation (CD80 (208), CD86 (209)) and BcR signaling pathways (IBTK (210)). Other genes found were related to epigenetic regulation (HDAC, HDAC9, DNMT3B). 


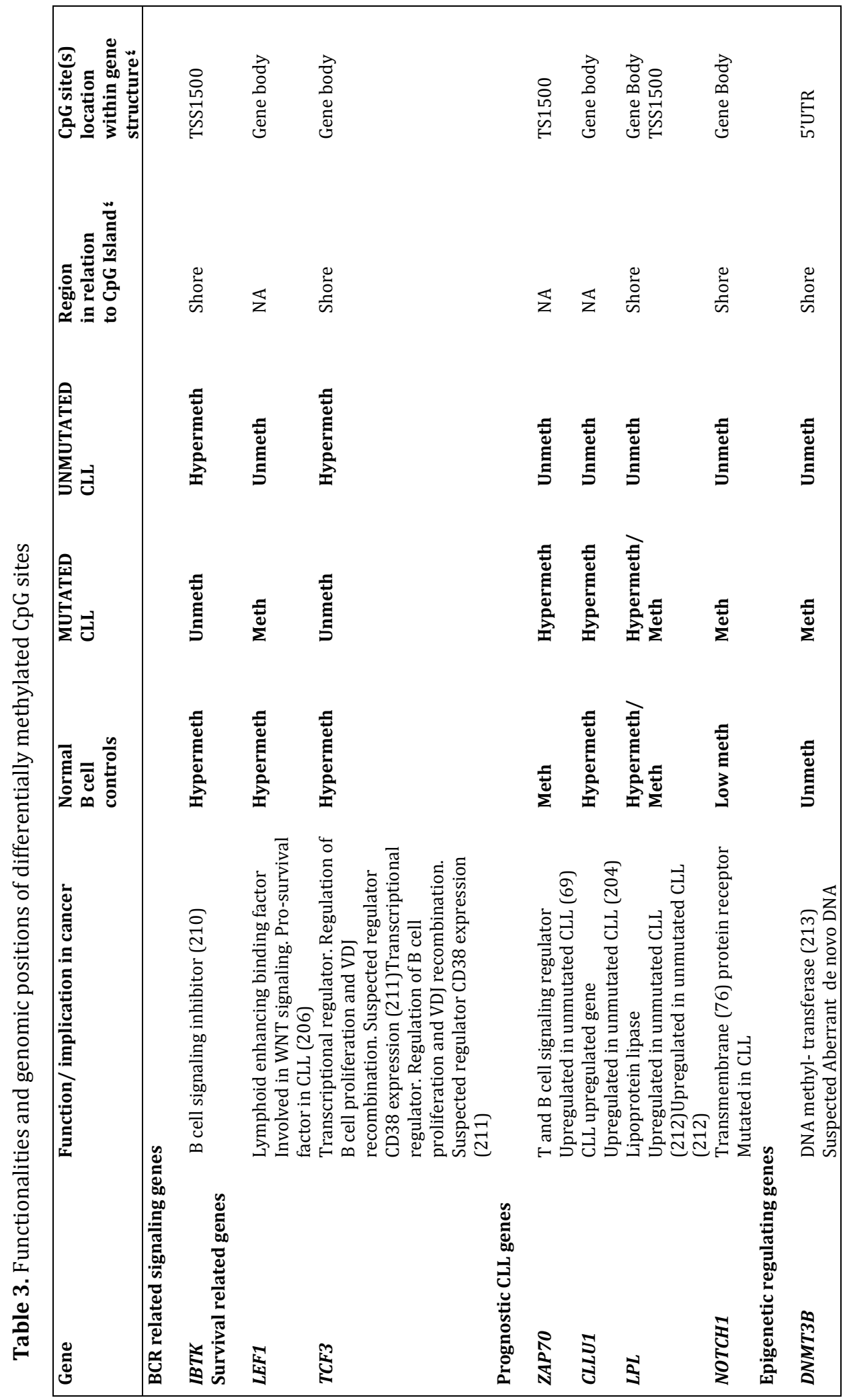




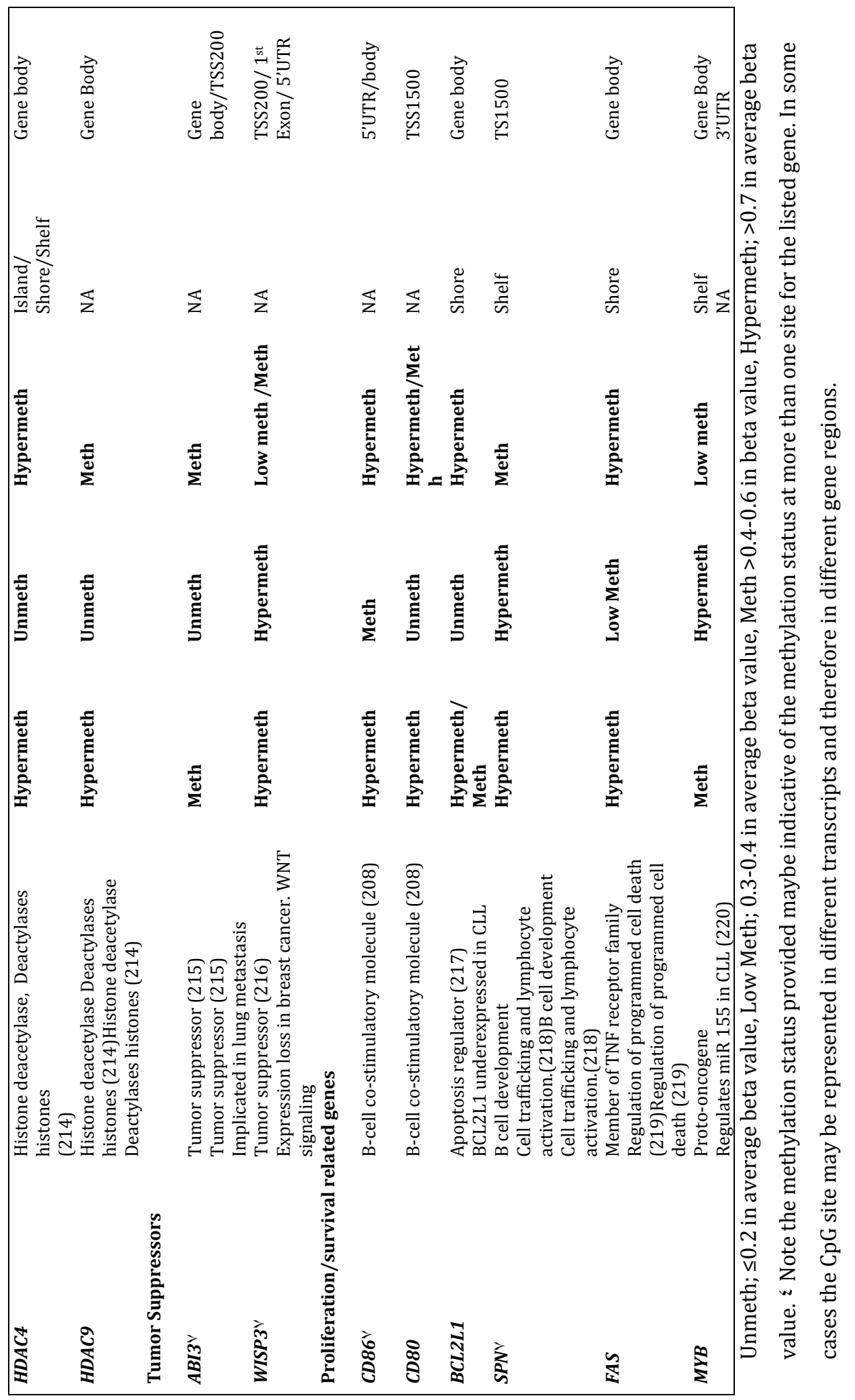


One of the enriched canonical pathways highlighted through ingenuity pathway analysis (IPA) was the "molecular mechanisms of cancer pathway". Within this pathway we could identify established genes/pathways implicated in CLL, such as genes belonging to the TGF- $\beta$ and the NF- $\kappa B / T N F$ pathways. The NF- $\kappa B / T N F$ pathway is highly interesting since TNF, TNFRSF8 (CD30), and two TNF-receptor genes, TNFSF1A and TNFRSF1B, recently shown to be redox controlled by protein-disulfide isomerase (PDI) in complex with Trx (221), were found to be differentially methylated in M and UM CLL.

Currently, the extent to which DNA methylation levels change with respect to time and treatment remains largely unknown in cancer. In the second part of paper III, we sought to determine changes of for the global DNA methylation pattern potentially occurring over time. By comparing paired diagnostic and follow-up (5-8 years) samples, we could for the first time show that the global methylation pattern is relatively stable over time. No recurrent differentially methylated sites were noted over time within the IGHV M subgroup and very few changes in the IGHV UM cases. When analyzing the intraindividual changes however, a larger difference in the number of non-recurrent differentially methylated sites were noted over time between IGHV M and IGHV UM cases. More specifically, analysis revealed IGHV UM patients to have a higher number of differentially methylated sites compared with IGHV M patients when measured longitudinally. These non-recurrent changes in IGHV UM cases are however minor (overall global changes $<1 \%$ ), taking into account the 485,000 sites available on the array.

The activity status and proliferative activity are known to differ in CLL PB and LN compartments. Recently, differential gene expression profiles have been found for patient-matched samples originating from the PB and LN in CLL. Genes involved in proliferation and active BcR signaling were shown to be highly expressed in the LN compartment compared with the PB (110). In the third part of paper III, we hypothesized that DNA methylation may partake in the mechanism of differential gene expression seen within the different compartments of CLL. In contrast to our hypothesis, while comparing patient-matched CLL cells derived from PB and LN, we found that global DNA methylation is rather similar in the two compartments. In summary, it seems like, unlike gene expression, DNA methylation of CLL cells from resting and proliferative compartments is less influenced by microenvironmental factors. 


\section{SHP-1 expression and activity: comparison of resting and active compartments in CLL (Paper IV)}

SHP-1 is a protein phosphotyrosine phosphatase (PTP) which modulates intracellular signaling and thus regulates cell activation, proliferation, differentiation, and migration. It has also been shown to contribute to maintenance of tolerance to self-Ags (124). SHP1 is a negative regulator of signal transduction induced by a number of cell receptors including the BcR. SHP-1 is often downregulated in lymphoid malignancies and it has been shown that lymphoma/leukemia cells with highly aggressive profile lack SHP-1 expression in vitro, suggesting that loss of SHP-1 expression might be associated with both malignant transformation and tumor cell aggressiveness $(222,223)$. As also described above, there are now several lines of evidence highlighting the importance of chronic Ag stimulation and BcR signaling in CLL pathogenesis (2, 3, 140, 145, 224). Considering that SHP-1 is a key phosphatase for the control of BcR signaling, we hypothesized in paper IV that, SHP-1 expression and/or activity should be lower in the LN proliferative compartment compared with the resting PB compartment. However, in contrast to our hypothesis, SHP-1 expression and activity/phosphorylation status did not differ significantly in PB CLL cells as, compared to LN derived CLL cells from the same donor.

SHP-1 protein was previously found to be equally expressed in CLL PB cells and normal B cells from healthy donors (225). In CLL, SHP-1 was expressed both in cytosolic and membrane fractions in contrast to normal B cells where it was only expressed in the cytosol. In CLL, CD5 is phosphorylated by LYN, and by this phosphorylation becomes a docking site for SHP-1. Once at the plasma membrane, SHP-1 is phosphorylated by LYN only at tyrosine residues and hence becomes activated and thus can de-phosphorylate downstream signaling molecules. SHP-1 in the cytosol is phosphorylated at serine S591 and its activity is thus inhibited (226). While phosphorylation of tyrosine Y536 and Y564 have been shown to activate SHP-1 and to increase its PTP activity, phosphorylation of serine S591 have been shown to be inhibitory when targeted by PKC $(227,228)$. We studied SHP-1 mRNA, protein expression and phosphorylation of whole cell lysates from CLL PB and LN. Although we see differences in SHP-1 mRNA levels with higher levels of SHP-1 expressed in PB than in LN, we could not show any significant differences in SHP1 protein levels (Figure 11). 
A

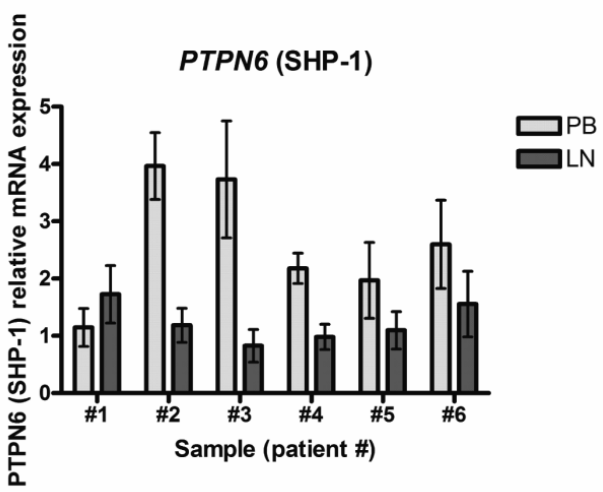

B

SHP-1

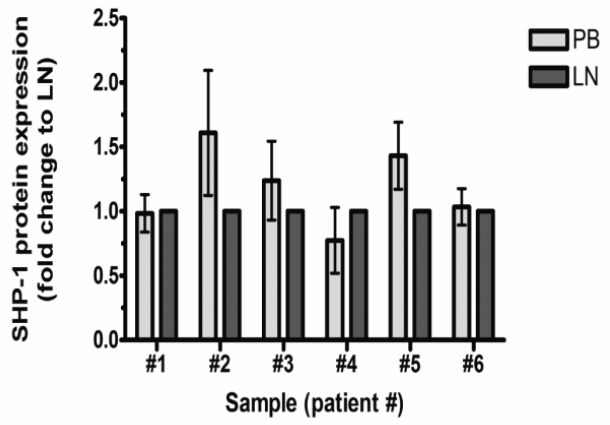

Figure 11. PTPN6 and SHP-1 expression in PB and LN samples

$C D 5^{+} C D 19^{+}$cells from 6 matched $P B$ and $L N$ patient samples were purified by negative selection. A. PTPN6 (SHP-1) gene expression levels were determined by Q-PCR. B. Total cell extracts were prepared and the amounts of SHP-1 and $\beta$-actin were determined by Western blot analysis. Densiometric analysis were performed and relative expression was calculated as optical density (OD) ratio of SHP-1/OD $\beta$-actin.

We could detect SHP-1 phosphorylation on both tyrosine and serine residues in all patients, however no significant differences were found in the two compartments (Figure 12). Phosphorylation of SHP-1 was however, down-regulated in BcR/ anti-IgM stimulated vs unstimulated PB cells (Figure 13). 
A

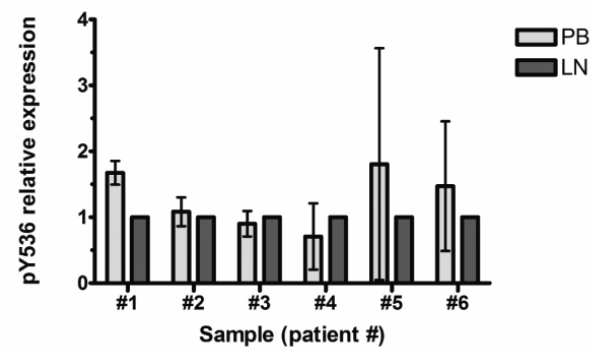

B

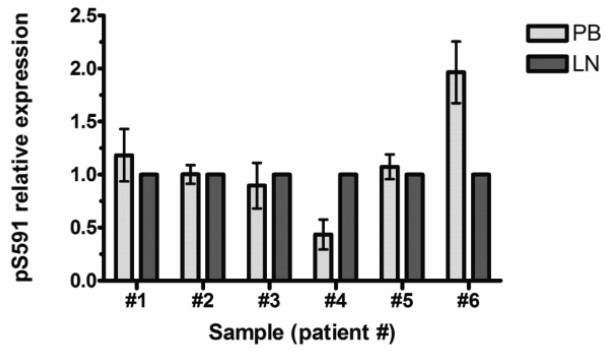

Figure 12. SHP-1 phosphorylation in matched PB and LN samples

$C D 5^{+} \mathrm{CD} 19^{+}$cells from 6 matched $P B$ and $L N$ patient samples were purified by negative selection. Whole-cell lysates were analyzed by immunoblotting with anti-pY536-SHP-1, anti-pS591-SHP-1, anti-SH-PTP1 or anti- $\beta$-actin. Densiometric analysis were performed and relative expression was calculated as optical density (OD) ratio of pY536/OD of total SHP-1 (A) or OD ratio of pS591/OD of total SHP-1 (B) and normalized to $\beta$-actin.

A

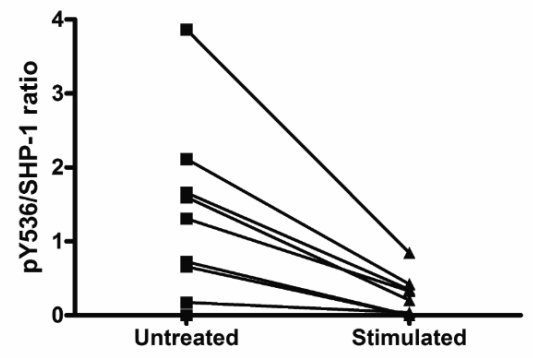

B

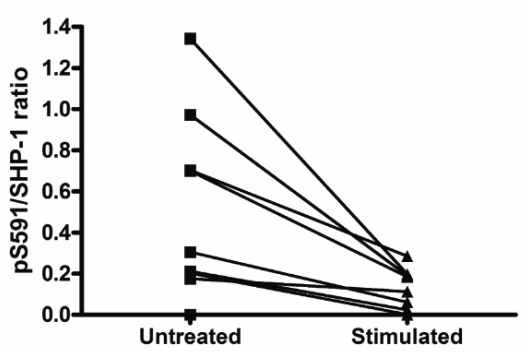

Figure 13. Effect of anti-IgM in PB cells on SHP-1 phosphorylation

Purified $C D 5^{+} C D 19^{+}$cells from 10 matched $P B$ and $L N$ patient samples were cultured in the absence or presence of $16 \mu \mathrm{g} / \mathrm{ml}$ anti-IgM for $48 \mathrm{~h}$. Whole-cell lysates were analyzed by immunoblotting with anti-pY536-SHP-1, anti-pS591-SHP-1, anti-SH-PTP1 or anti- $\beta$-actin. Densitometric analyses of untreated and anti-IgM treated (stimulated) samples are shown and data are presented as optical density (OD) ratio of pY536/OD of total SHP-1 (A) or OD ratio of pS591/OD of total SHP-1 (B) and normalized to $\beta$-actin. 
In conclusion, we see de-phosphorylation/inactivation of SHP-1 in vitro, however in vivo SHP-1 is still activated and phosphorylated in activated LN cells. B cells with an anergic/unresponsive profile is maintained in vivo. This is in line with findings in B1 cells in which CD5-SHP-1 association persists upon BcR engagement. This limits B cell response and retain B1 cells in its anergic state (229). This observation is noteworthy, since CLL B cells share several properties with B1 B cells, including CD5 ${ }^{+}$expression and the anergic condition $(224,230)$. Studies have shown that the active site cysteines of PTPs can be oxidized, thus inhibiting its enzymatic activity. This could also be the case in our study. Further studies are necessary to evaluate activity of SHP-1 in cells from PB and LN. 
In this thesis we have investigated influence of the cellular microenvironment as well as antigen on the pathogenesis of chronic lymphocytic leukemia and we found that:

\section{Paper I}

- The small redox molecule Trx was secreted from FRCs and FDCs positioned in the proliferation centers in close contact with proliferating CLL cells. Inhibition of Trx in culture promoted increased cell death, implicating an important role for Trx in CLL cell survival. Trx is probably one soluble molecule among several others important for survival and cell growth of CLL cells.

\section{Paper II}

- Cognate antigen for the aggressive CLL subset \#1, oxLDL, could not activate or induce proliferation in subset \#1 CLL cells. This inability to respond to antigen via $\mathrm{BcR}$ was due to un-responsivity/anergy as could be shown by high basal level of pERK as well as regained responsiveness after $48 \mathrm{~h}$ antigen wash-out. Furthermore, TLR9 engagement was able to breach the anergic state in some patients. These results indicates that clonal expansion in CLL subset \#1 are brought about by several other factors and or that sub-clones with different responsivity exists.

\section{Paper III}

- On a larger scale than previously reported we revealed a large number of differentially methylated CpG sites between IGHV M and IGHV UM cases, with the majority of sites positioned outside annotated $\mathrm{CpG}$ islands. For example the known CLL prognostic genes CLLU1, LPL, ZAP70 and NOTCH1, the inhibitor IBTK gene and numerous TGF- $\beta$ and NF- $\kappa B / T N F$ pathway genes were alternatively methylated between subgroups. These data support the notion that aberrant DNA methylation contributes to the differential outcome that can be seen in different prognostic CLL subgroups. 
- When searching for differences in DNA methylation over time we could conclude that the global methylation pattern was rather stable with few recurrent changes noted within subgroups, indicating that aberrant DNA methylation events are early events in CLL pathogenesis. Also between patient-matched CLL cells derived from different compartments, PB (resting) and LN (proliferating), the global DNA methylation was rather similar. Overall, it appears that unlike gene expression, DNA methylation of CLL cells from different compartments is less influenced by microenvironmental factors.

\section{Paper IV}

- SHP-1 protein expression and activity/phosphorylation status in PB CLL cells, compared to LN derived CLL cells from the same donor, did not differ significantly. Absence of SHP-1 protein and PTPN6 gene downregulation and/or activation in proliferative centers/LNs in vivo may be part of a strategy for anergy maintenance in CLL, or alternatively it may indicate loss of function by oxidation or mutation of the catalytic site amino acids.

Taken together, this thesis, add another piece to the puzzle, on how the microenvironment and antigens influence CLL pathogenesis. Since great variations among individuals are seen, further studies in different groups of patients are necessary to elucidate the importance of antigen for the development of CLL.

In the long run, studies on microenvironmental influence, cell signaling, genomic and epigenetic modifications, comparing different subsets of patients, could lead to a more individualized treatment. 


\section{ACKNOWLEDGEMENTS}

I have many persons I want to thank, who supported me in different ways, for making this thesis possible.

First of all I want to thank my first supervisor Eva Bäckman for introducing me to CLL and for inspiring me to start as a PhD-student. Too bad we couldn't finish the journey together.

A special thank you to my present supervisor Anders Rosén for believing in me and for giving me the opportunity to work as a PhD-student in your lab. Thank you for always being there to answer my questions, for giving me your support and to share your great knowledge in many different areas and at the same time giving me freedom to explore science on my own. Thank you!

Richard Rosenquist Brandell my co-supervisor for fruitful collaborations and for always taking time to answer my questions.

Björn Ingelsson my closest co-worker and roommate for interesting discussions about science and life in general. Thank you for your support whenever I have been in doubt or have had a bad day.

Former members of the group for being good colleagues and friends;

Anita Söderberg for sharing your wisdom and life experience and of course your excellent laboratory skills.

Eva Hellqvist and Anna Lanemo Myhrinder for introducing me to the lab. It was really fun times when you two were around. I miss you and I miss our game dates.

Vivian Morad for being a very kind and caring person.

Chamilly Evaldsson you are one of the smartest persons I know, thank you for your friendship, support, and for the many interesting discussions on CLL.

Former and present co-workers at Cell Biology floor 13 for bringing joy and laughter to the lunchbreaks and to all our activities; Anita L, Annelie, Antonio, Birgitta, Cathrine, 
Christine, Cilla, Colm, Danka, Emelie, Hanna, Huan, Ingemar, Ivana, Jacob, Kerstin, Mika, Mikael, Narges, Olof, Paula, Rikard, Sara, Susana, Tejaswi, and Viviana

Thanks to all our collaborators! Nicola Cahill, Lesley Ann Sutton, Larry Mansouri, Mattias Jansson and Fiona Murray from Uppsala, Kostas Stamatopoulos from Greece, Christian Geisler and Lone Bredo Pedersen from Denmark, Sohvi Hörkkö from Finland, Annette Gjörloff Wingren and Zahra El-Schich from Malmö

The Haeamatology department, especially Kourosh Lotfi and Mats Linderholm

Friends outside the walls of cell biology. Carro, Cissi, Charlotta, Stina \& Johan, Linda \& Palle, Therese \& Peter, Therese \& Jonas the Västerlösa-crue and the Freja-moms for just being really good friends.

Ett stort tack till min "nya" familj, ni är superhärliga hela bunten och det är alltid lika kul att träffas. Ser fram emot sommarsemester i Spanien tillsammans! Ett speciellt tack till min svärmor Monica som ställer upp i ur och skur, vad skulle vi ha gjort utan dig det senaste halvåret.

Ett stort tack vill jag såklart även rikta till min älskade familj som består av mamma, pappa och syskon med familjer, för att ni alltid finns där för mig och min familj, att ni tror på mig och att ni stöttar mig på alla sätt ni kan. Ni betyder mycket för mig.

Tack Marcus, mitt livs kärlek, för att du är den snällaste, mest omtänksamma, och mest stöttande man en kvinna kan ha. Älskar dig! Arvid, Måns och den lilla i magen, mina små älsklingar som förgyller varje dag av mitt liv

This research was supported by:

The Swedish Cancer Association, East Gothia Cancer Foundation, Borgholm Rotary Foundation, Lion's Cancer Research Foundation, Swedish research council and Linköping University Hospital Funds, 


\section{REFERENCES}

1. Tobin G, Thunberg U, Karlsson K, Murray F, Laurell A, Willander K, et al. Subsets with restricted immunoglobulin gene rearrangement features indicate a role for antigen selection in the development of chronic lymphocytic leukemia. Blood. 2004;104(9):2879-85.

2. Stamatopoulos K, Belessi C, Moreno C, Boudjograh M, Guida G, Smilevska T, et al. Over $20 \%$ of patients with chronic lymphocytic leukemia carry stereotyped receptors: Pathogenetic implications and clinical correlations. Blood. 2007;109(1):259-70.

3. Murray F, Darzentas N, Hadzidimitriou A, Tobin G, Boudjogra M, Scielzo C, et al. Stereotyped patterns of somatic hypermutation in subsets of patients with chronic lymphocytic leukemia: implications for the role of antigen selection in leukemogenesis. Blood. 2008;111(3):1524-33.

4. Janeway CA, Jr., Medzhitov R. Innate immune recognition. Annual review of immunology. 2002;20:197-216.

5. Kawai T, Akira S. The roles of TLRs, RLRs and NLRs in pathogen recognition. Int Immunol. 2009;21(4):317-37.

6. Miller YI, Choi SH, Wiesner P, Fang L, Harkewicz R, Hartvigsen K, et al. Oxidationspecific epitopes are danger-associated molecular patterns recognized by pattern recognition receptors of innate immunity. Circ Res. 2011;108(2):235-48.

7. LeBien TW, Tedder TF. B lymphocytes: how they develop and function. Blood. 2008;112(5):1570-80.

8. Ghia P, Rosenquist R, Davi F. Immunoglobulin Gene Analysis in Chronic Lymphocytic Leukemia. Milan: Wolters Kluwer Health Italy Ltd; 2009.

9. Bassing $\mathrm{CH}$, Swat $\mathrm{W}$, Alt FW. The mechanism and regulation of chromosomal V(D)J recombination. Cell. 2002;109 Suppl:S45-55.

10. Gellert M. V(D)J recombination: RAG proteins, repair factors, and regulation. Annual review of biochemistry. 2002;71:101-32.

11. Meffre E, Casellas R, Nussenzweig MC. Antibody regulation of B cell development. Nature immunology. 2000;1(5):379-85.

12. Hardy RR, Kincade PW, Dorshkind K. The protean nature of cells in the B lymphocyte lineage. Immunity. 2007;26(6):703-14. 
13. Batista FD, Harwood NE. The who, how and where of antigen presentation to B cells. Nature reviews Immunology. 2009;9(1):15-27.

14. Cerutti A, Puga I, Cols M. Innate control of B cell responses. Trends in immunology. 2011;32(5):202-11.

15. Klein U, Dalla-Favera R. Germinal centres: role in B-cell physiology and malignancy. Nature reviews Immunology. 2008;8(1):22-33.

16. MacLennan IC. Germinal centers. Annual review of immunology. 1994;12:117-39.

17. Chien NC, Pollock RR, Desaymard C, Scharff MD. Point mutations cause the somatic diversification of IgM and IgG2a antiphosphorylcholine antibodies. The Journal of experimental medicine. 1988;167(3):954-73.

18. Di Noia JM, Neuberger MS. Molecular mechanisms of antibody somatic hypermutation. Annual review of biochemistry. 2007;76:1-22.

19. Victora GD, Nussenzweig MC. Germinal centers. Annual review of immunology. 2012;30:429-57.

20. Allen CD, Okada T, Cyster JG. Germinal-center organization and cellular dynamics. Immunity. 2007;27(2):190-202.

21. Nemazee D. Antigen receptor 'capacity' and the sensitivity of self-tolerance. Immunology today. 1996;17(1):25-9.

22. Wardemann H, Yurasov S, Schaefer A, Young JW, Meffre E, Nussenzweig MC. Predominant autoantibody production by early human B cell precursors. Science. 2003;301(5638):1374-7.

23. Gallegos AM, Bevan MJ. Driven to autoimmunity: the nod mouse. Cell. 2004;117(2):149-51.

24. Nemazee DA, Burki K. Clonal deletion of B lymphocytes in a transgenic mouse bearing anti-MHC class I antibody genes. Nature. 1989;337(6207):562-6.

25. Halverson R, Torres RM, Pelanda R. Receptor editing is the main mechanism of B cell tolerance toward membrane antigens. Nature immunology. 2004;5(6):645-50.

26. Hippen KL, Schram BR, Tze LE, Pape KA, Jenkins MK, Behrens TW. In vivo assessment of the relative contributions of deletion, anergy, and editing to B cell self-tolerance. Journal of immunology. 2005;175(2):909-16.

27. Gauld SB, Benschop RJ, Merrell KT, Cambier JC. Maintenance of B cell anergy requires constant antigen receptor occupancy and signaling. Nature immunology. 2005;6(11):1160-7. 
28. Cambier JC, Gauld SB, Merrell KT, Vilen BJ. B-cell anergy: from transgenic models to naturally occurring anergic B cells? Nature reviews Immunology. 2007;7(8):633-43.

29. Briles DE, Nahm M, Schroer K, Davie J, Baker P, Kearney J, et al. Antiphosphocholine antibodies found in normal mouse serum are protective against intravenous infection with type 3 streptococcus pneumoniae. The Journal of experimental medicine. 1981;153(3):694-705.

30. Haas KM, Poe JC, Steeber DA, Tedder TF. B-1a and B-1b cells exhibit distinct developmental requirements and have unique functional roles in innate and adaptive immunity to S. pneumoniae. Immunity. 2005;23(1):7-18.

31. Baumgarth N, Herman OC, Jager GC, Brown LE, Herzenberg LA, Chen J. B-1 and B-2 cell-derived immunoglobulin $\mathrm{M}$ antibodies are nonredundant components of the protective response to influenza virus infection. The Journal of experimental medicine. 2000;192(2):271-80.

32. Binder CJ, Silverman GJ. Natural antibodies and the autoimmunity of atherosclerosis. Springer Semin Immunopathol. 2005;26(4):385-404.

33. Forster I, Rajewsky K. Expansion and functional activity of Ly-1+ B cells upon transfer of peritoneal cells into allotype-congenic, newborn mice. European journal of immunology. 1987;17(4):521-8.

34. Sidman CL, Shultz LD, Hardy RR, Hayakawa K, Herzenberg LA. Production of immunoglobulin isotypes by Ly-1+ B cells in viable motheaten and normal mice. Science. 1986;232(4756):1423-5.

35. Gu H, Forster I, Rajewsky K. Sequence homologies, N sequence insertion and JH gene utilization in VHDJH joining: implications for the joining mechanism and the ontogenetic timing of Ly1 B cell and B-CLL progenitor generation. The EMBO journal. 1990;9(7):2133-40.

36. Baumgarth N. The double life of a B-1 cell: self-reactivity selects for protective effector functions. Nature reviews Immunology. 2011;11(1):34-46.

37. Baumgarth N. Innate-like B cells and their rules of engagement. Advances in experimental medicine and biology. 2013;785:57-66.

38. Zhong X, Gao W, Degauque N, Bai C, Lu Y, Kenny J, et al. Reciprocal generation of Th1/Th17 and T(reg) cells by B1 and B2 B cells. European journal of immunology. 2007;37(9):2400-4. 
39. Wong SC, Chew WK, Tan JE, Melendez AJ, Francis F, Lam KP. Peritoneal CD5+ B-1 cells have signaling properties similar to tolerant B cells. The Journal of biological chemistry. 2002;277(34):30707-15.

40. Griffin DO, Holodick NE, Rothstein TL. Human B1 cells in umbilical cord and adult peripheral blood express the novel phenotype CD20+CD27+ CD43+ CD70. The Journal of experimental medicine. 2011;208(1):67-80.

41. Covens K, Verbinnen B, Geukens N, Meyts I, Schuit F, Van Lommel L, et al. Characterization of proposed human B-1 cells reveals pre-plasmablast phenotype. Blood. 2013;121(26):5176-83.

42. Descatoire M, Weill JC, Reynaud CA, Weller S. A human equivalent of mouse B-1 cells? The Journal of experimental medicine. 2011;208(13):2563-4.

43. Perez-Andres M, Grosserichter-Wagener C, Teodosio C, van Dongen JJ, Orfao A, van Zelm MC. The nature of circulating CD27+CD43+ B cells. The Journal of experimental medicine. 2011;208(13):2565-6.

44. Griffin DO, Holodick NE, Rothstein TL. Human B1 cells are CD3-: A reply to "A human equivalent of mouse B-1 cells?" and "The nature of circulating CD27+CD43+ B cells". The Journal of experimental medicine. 2011;208(13):2566-9.

45. Weill JC, Weller S, Reynaud CA. Human marginal zone B cells. Annual review of immunology. 2009;27:267-85.

46. Linet MS, Schubauer-Berigan MK, Weisenburger DD, Richardson DB, Landgren O, Blair A, et al. Chronic lymphocytic leukaemia: an overview of aetiology in light of recent developments in classification and pathogenesis. British journal of haematology. 2007;139(5):672-86.

47. Siegel R, DeSantis C, Virgo K, Stein K, Mariotto A, Smith T, et al. Cancer treatment and survivorship statistics, 2012. CA: a cancer journal for clinicians. 2012;62(4):220-41.

48. Rozman C, Montserrat E. Chronic lymphocytic leukemia. The New England journal of medicine. 1995;333(16):1052-7.

49. Molica S. Sex differences in incidence and outcome of chronic lymphocytic leukemia patients. Leukemia \& lymphoma. 2006;47(8):1477-80.

50. Linet MS, Van Natta ML, Brookmeyer R, Khoury MJ, McCaffrey LD, Humphrey RL, et al. Familial cancer history and chronic lymphocytic leukemia. A case-control study. American journal of epidemiology. 1989;130(4):655-64. 
51. Weiss NS. Geographical variation in the incidence of the leukemias and lymphomas. National Cancer Institute monograph. 1979(53):139-42.

52. Boggs DR, Chen SC, Zhang ZN, Zhang A. Chronic lymphocytic leukemia in China. American journal of hematology. 1987;25(3):349-54.

53. Matutes E, Owusu-Ankomah K, Morilla R, Garcia Marco J, Houlihan A, Que TH, et al. The immunological profile of B-cell disorders and proposal of a scoring system for the diagnosis of CLL. Leukemia. 1994;8(10):1640-5.

54. Moreau EJ, Matutes E, A'Hern RP, Morilla AM, Morilla RM, Owusu-Ankomah KA, et al. Improvement of the chronic lymphocytic leukemia scoring system with the monoclonal antibody SN8 (CD79b). American journal of clinical pathology. 1997;108(4):378-82.

55. Hallek M, Cheson BD, Catovsky D, Caligaris-Cappio F, Dighiero G, Dohner H, et al. Guidelines for the diagnosis and treatment of chronic lymphocytic leukemia: a report from the International Workshop on Chronic Lymphocytic Leukemia updating the National Cancer Institute-Working Group 1996 guidelines. Blood. 2008;111(12):5446-56.

56. Binet JL, Auquier A, Dighiero G, Chastang C, Piguet H, Goasguen J, et al. A new prognostic classification of chronic lymphocytic leukemia derived from a multivariate survival analysis. Cancer. 1981;48(1):198-206.

57. Rai KR, Sawitsky A, Cronkite EP, Chanana AD, Levy RN, Pasternack BS. Clinical staging of chronic lymphocytic leukemia. Blood. 1975;46(2):219-34.

58. Schroeder HW, Jr., Dighiero G. The pathogenesis of chronic lymphocytic leukemia: analysis of the antibody repertoire. Immunology today. 1994;15(6):288-94.

59. Damle RN, Wasil T, Fais F, Ghiotto F, Valetto A, Allen SL, et al. Ig V gene mutation status and CD38 expression as novel prognostic indicators in chronic lymphocytic leukemia. Blood. 1999;94(6):1840-7.

60. Hamblin TJ, Davis Z, Gardiner A, Oscier DG, Stevenson FK. Unmutated Ig V(H) genes are associated with a more aggressive form of chronic lymphocytic leukemia. Blood. 1999;94(6):1848-54.

61. Deaglio S, Vaisitti T, Aydin S, Ferrero E, Malavasi F. In-tandem insight from basic science combined with clinical research: CD38 as both marker and key component of the pathogenetic network underlying chronic lymphocytic leukemia. Blood. 2006;108(4):1135-44. 
62. Damle RN, Ghiotto F, Valetto A, Albesiano E, Fais F, Yan XJ, et al. B-cell chronic lymphocytic leukemia cells express a surface membrane phenotype of activated, antigen-experienced B lymphocytes. Blood. 2002;99(11):4087-93.

63. Hamblin TJ, Orchard JA, Ibbotson RE, Davis Z, Thomas PW, Stevenson FK, et al. CD38 expression and immunoglobulin variable region mutations are independent prognostic variables in chronic lymphocytic leukemia, but CD38 expression may vary during the course of the disease. Blood. 2002;99(3):1023-9.

64. Ibrahim S, Keating M, Do KA, O'Brien S, Huh YO, Jilani I, et al. CD38 expression as an important prognostic factor in B-cell chronic lymphocytic leukemia. Blood. 2001;98(1):181-6.

65. Krober A, Seiler T, Benner A, Bullinger L, Bruckle E, Lichter P, et al. V(H) mutation status, CD38 expression level, genomic aberrations, and survival in chronic lymphocytic leukemia. Blood. 2002;100(4):1410-6.

66. Chan AC, Iwashima M, Turck CW, Weiss A. ZAP-70: a 70 kd protein-tyrosine kinase that associates with the TCR zeta chain. Cell. 1992;71(4):649-62.

67. Nolz JC, Tschumper RC, Pittner BT, Darce JR, Kay NE, Jelinek DF. ZAP-70 is expressed by a subset of normal human B-lymphocytes displaying an activated phenotype. Leukemia. 2005;19(6):1018-24.

68. Cutrona G, Colombo M, Matis S, Reverberi D, Dono M, Tarantino V, et al. B lymphocytes in humans express ZAP-70 when activated in vivo. European journal of immunology. 2006;36(3):558-69.

69. Wiestner A, Rosenwald A, Barry TS, Wright G, Davis RE, Henrickson SE, et al. ZAP-70 expression identifies a chronic lymphocytic leukemia subtype with unmutated immunoglobulin genes, inferior clinical outcome, and distinct gene expression profile. Blood. 2003;101(12):4944-51.

70. Rosenwald A, Alizadeh AA, Widhopf G, Simon R, Davis RE, Yu X, et al. Relation of gene expression phenotype to immunoglobulin mutation genotype in B cell chronic lymphocytic leukemia. The Journal of experimental medicine. 2001;194(11):163947.

71. Dohner H, Stilgenbauer S, Benner A, Leupolt E, Krober A, Bullinger L, et al. Genomic aberrations and survival in chronic lymphocytic leukemia. The New England journal of medicine. 2000;343(26):1910-6. 
72. Calin GA, Dumitru CD, Shimizu M, Bichi R, Zupo S, Noch E, et al. Frequent deletions and down-regulation of micro- RNA genes miR15 and miR16 at 13q14 in chronic lymphocytic leukemia. Proceedings of the National Academy of Sciences of the United States of America. 2002;99(24):15524-9.

73. Cimmino A, Calin GA, Fabbri M, Iorio MV, Ferracin M, Shimizu M, et al. miR-15 and miR-16 induce apoptosis by targeting BCL2. Proceedings of the National Academy of Sciences of the United States of America. 2005;102(39):13944-9.

74. Bullrich F, Rasio D, Kitada S, Starostik P, Kipps T, Keating M, et al. ATM mutations in B-cell chronic lymphocytic leukemia. Cancer research. 1999;59(1):24-7.

75. Puente XS, Pinyol M, Quesada V, Conde L, Ordonez GR, Villamor N, et al. Wholegenome sequencing identifies recurrent mutations in chronic lymphocytic leukaemia. Nature. 2011;475(7354):101-5.

76. Fabbri G, Rasi S, Rossi D, Trifonov V, Khiabanian H, Ma J, et al. Analysis of the chronic lymphocytic leukemia coding genome: role of NOTCH1 mutational activation. The Journal of experimental medicine. 2011;208(7):1389-401.

77. Zenz T, Eichhorst B, Busch R, Denzel T, Habe S, Winkler D, et al. TP53 mutation and survival in chronic lymphocytic leukemia. Journal of clinical oncology : official journal of the American Society of Clinical Oncology. 2010;28(29):4473-9.

78. Zenz T, Vollmer D, Trbusek M, Smardova J, Benner A, Soussi T, et al. TP53 mutation profile in chronic lymphocytic leukemia: evidence for a disease specific profile from a comprehensive analysis of 268 mutations. Leukemia. 2010;24(12):2072-9.

79. el Rouby S, Thomas A, Costin D, Rosenberg CR, Potmesil M, Silber R, et al. p53 gene mutation in B-cell chronic lymphocytic leukemia is associated with drug resistance and is independent of MDR1/MDR3 gene expression. Blood. 1993;82(11):3452-9.

80. Wang L, Lawrence MS, Wan Y, Stojanov P, Sougnez C, Stevenson K, et al. SF3B1 and other novel cancer genes in chronic lymphocytic leukemia. The New England journal of medicine. 2011;365(26):2497-506.

81. Rossi D, Fangazio M, Rasi S, Vaisitti T, Monti S, Cresta S, et al. Disruption of BIRC3 associates with fludarabine chemorefractoriness in TP53 wild-type chronic lymphocytic leukemia. Blood. 2012;119(12):2854-62.

82. Rossi D, Rasi S, Fabbri G, Spina V, Fangazio M, Forconi F, et al. Mutations of NOTCH1 are an independent predictor of survival in chronic lymphocytic leukemia. Blood. 2012;119(2):521-9. 
83. Quesada V, Conde L, Villamor N, Ordonez GR, Jares P, Bassaganyas L, et al. Exome sequencing identifies recurrent mutations of the splicing factor SF3B1 gene in chronic lymphocytic leukemia. Nature genetics. 2012;44(1):47-52.

84. Del Giudice I, Rossi D, Chiaretti S, Marinelli M, Tavolaro S, Gabrielli S, et al. NOTCH1 mutations in +12 chronic lymphocytic leukemia (CLL) confer an unfavorable prognosis, induce a distinctive transcriptional profiling and refine the intermediate prognosis of +12 CLL. Haematologica. 2012;97(3):437-41.

85. Lopez C, Delgado J, Costa D, Conde L, Ghita G, Villamor N, et al. Different distribution of NOTCH1 mutations in chronic lymphocytic leukemia with isolated trisomy 12 or associated with other chromosomal alterations. Genes, chromosomes \& cancer. 2012;51(9):881-9.

86. SvenskaKLL-gruppen. Kronisk Lymfatisk Leukemi Nationella riktlinjer för utredning och behandling2013.

87. Chemotherapeutic options in chronic lymphocytic leukemia: a meta-analysis of the randomized trials. CLL Trialists' Collaborative Group. Journal of the National Cancer Institute. 1999;91(10):861-8.

88. Tam CS, O'Brien S, Wierda W, Kantarjian H, Wen S, Do KA, et al. Long-term results of the fludarabine, cyclophosphamide, and rituximab regimen as initial therapy of chronic lymphocytic leukemia. Blood. 2008;112(4):975-80.

89. Foon KA, Mehta D, Lentzsch S, Kropf P, Marks S, Lenzner D, et al. Long-term results of chemoimmunotherapy with low-dose fludarabine, cyclophosphamide and high-dose rituximab as initial treatment for patients with chronic lymphocytic leukemia. Blood. 2012;119(13):3184-5

90. Ponader S, Chen SS, Buggy JJ, Balakrishnan K, Gandhi V, Wierda WG, et al. The Bruton tyrosine kinase inhibitor PCI-32765 thwarts chronic lymphocytic leukemia cell survival and tissue homing in vitro and in vivo. Blood. 2012;119(5):1182-9.

91. Buchner M, Baer C, Prinz G, Dierks C, Burger M, Zenz T, et al. Spleen tyrosine kinase inhibition prevents chemokine- and integrin-mediated stromal protective effects in chronic lymphocytic leukemia. Blood. 2010;115(22):4497-506.

92. Herman SE, Gordon AL, Hertlein E, Ramanunni A, Zhang X, Jaglowski S, et al. Bruton tyrosine kinase represents a promising therapeutic target for treatment of chronic lymphocytic leukemia and is effectively targeted by PCI-32765. Blood. 2011;117(23):6287-96. 
93. Cheng S, Ma J, Guo A, Lu P, Leonard JP, Coleman M, et al. BTK inhibition targets in vivo CLL proliferation through its effects on B-cell receptor signaling activity. Leukemia. 2014;28(3):649-57.

94. de Rooij MF, Kuil A, Geest CR, Eldering E, Chang BY, Buggy JJ, et al. The clinically active BTK inhibitor PCI-32765 targets B-cell receptor- and chemokine-controlled adhesion and migration in chronic lymphocytic leukemia. Blood. 2012;119(11):2590-4.

95. Herman SE, Gordon AL, Wagner AJ, Heerema NA, Zhao W, Flynn JM, et al. Phosphatidylinositol 3-kinase-delta inhibitor CAL-101 shows promising preclinical activity in chronic lymphocytic leukemia by antagonizing intrinsic and extrinsic cellular survival signals. Blood. 2010;116(12):2078-88.

96. Hoellenriegel J, Meadows SA, Sivina M, Wierda WG, Kantarjian H, Keating MJ, et al. The phosphoinositide 3'-kinase delta inhibitor, CAL-101, inhibits B-cell receptor signaling and chemokine networks in chronic lymphocytic leukemia. Blood. 2011;118(13):3603-12.

97. Fiorcari S, Brown WS, McIntyre BW, Estrov Z, Maffei R, O'Brien S, et al. The PI3-kinase delta inhibitor idelalisib (GS-1101) targets integrin-mediated adhesion of chronic lymphocytic leukemia (CLL) cell to endothelial and marrow stromal cells. PloS one. 2013;8(12):e83830.

98. Ghia P, Chiorazzi N, Stamatopoulos K. Microenvironmental influences in chronic lymphocytic leukaemia: the role of antigen stimulation. J Intern Med. 2008;264(6):549-62.

99. Burger JA, Ghia P, Rosenwald A, Caligaris-Cappio F. The microenvironment in mature B-cell malignancies: a target for new treatment strategies. Blood. 2009;114(16):3367-75.

100. Stein H, Bonk A, Tolksdorf G, Lennert K, Rodt H, Gerdes J. Immunohistologic analysis of the organization of normal lymphoid tissue and non-Hodgkin's lymphomas. The journal of histochemistry and cytochemistry : official journal of the Histochemistry Society. 1980;28(8):746-60.

101. Burger JA, Tsukada N, Burger M, Zvaifler NJ, Dell'Aquila M, Kipps TJ. Bloodderived nurse-like cells protect chronic lymphocytic leukemia B cells from spontaneous apoptosis through stromal cell-derived factor-1. Blood. 2000;96(8):2655-63. 
102. Ghia P, Strola G, Granziero L, Geuna M, Guida G, Sallusto F, et al. Chronic lymphocytic leukemia B cells are endowed with the capacity to attract CD4+, CD40L+ T cells by producing CCL22. European journal of immunology. 2002;32(5):1403-13. 103. Bernal A, Pastore RD, Asgary Z, Keller SA, Cesarman E, Liou HC, et al. Survival of leukemic B cells promoted by engagement of the antigen receptor. Blood. 2001;98(10):3050-7.

104. Deaglio S, Vaisitti T, Bergui L, Bonello L, Horenstein AL, Tamagnone L, et al. CD38 and CD100 lead a network of surface receptors relaying positive signals for BCLL growth and survival. Blood. 2005;105(8):3042-50.

105. Messmer BT, Messmer D, Allen SL, Kolitz JE, Kudalkar P, Cesar D, et al. In vivo measurements document the dynamic cellular kinetics of chronic lymphocytic leukemia B cells. The Journal of clinical investigation. 2005;115(3):755-64.

106. Totterman TH, Carlsson M, Simonsson B, Bengtsson M, Nilsson K. T-cell activation and subset patterns are altered in B-CLL and correlate with the stage of the disease. Blood. 1989;74(2):786-92.

107. Kitada S, Zapata JM, Andreeff M, Reed JC. Bryostatin and CD40-ligand enhance apoptosis resistance and induce expression of cell survival genes in B-cell chronic lymphocytic leukaemia. British journal of haematology. 1999;106(4):9951004.

108. Van den Hove LE, Van Gool SW, Vandenberghe P, Bakkus M, Thielemans K, Boogaerts MA, et al. CD40 triggering of chronic lymphocytic leukemia B cells results in efficient alloantigen presentation and cytotoxic $\mathrm{T}$ lymphocyte induction by upregulation of CD80 and CD86 costimulatory molecules. Leukemia. 1997;11(4):57280.

109. Burger JA, Quiroga MP, Hartmann E, Burkle A, Wierda WG, Keating MJ, et al. High-level expression of the T-cell chemokines CCL3 and CCL4 by chronic lymphocytic leukemia B cells in nurselike cell cocultures and after BCR stimulation. Blood. 2009;113(13):3050-8.

110. Herishanu Y, Perez-Galan P, Liu D, Biancotto A, Pittaluga S, Vire B, et al. The lymph node microenvironment promotes B-cell receptor signaling, NF-kappaB activation, and tumor proliferation in chronic lymphocytic leukemia. Blood. 2011;117(2):563-74. 
111. Nishio M, Endo T, Tsukada N, Ohata J, Kitada S, Reed JC, et al. Nurselike cells express BAFF and APRIL, which can promote survival of chronic lymphocytic leukemia cells via a paracrine pathway distinct from that of SDF-1alpha. Blood. 2005;106(3):1012-20.

112. Binder M, Lechenne B, Ummanni R, Scharf C, Balabanov S, Trusch M, et al. Stereotypical chronic lymphocytic leukemia B-cell receptors recognize survival promoting antigens on stromal cells. PloS one. 2010;5(12):e15992.

113. Pedersen IM, Kitada S, Leoni LM, Zapata JM, Karras JG, Tsukada N, et al. Protection of CLL B cells by a follicular dendritic cell line is dependent on induction of Mcl-1. Blood. 2002;100(5):1795-801.

114. Granziero L, Circosta P, Scielzo C, Frisaldi E, Stella S, Geuna M, et al. CD100/Plexin-B1 interactions sustain proliferation and survival of normal and leukemic CD5+ B lymphocytes. Blood. 2003;101(5):1962-9.

115. Circu ML, Aw TY. Reactive oxygen species, cellular redox systems, and apoptosis. Free Radic Biol Med. 2010;48(6):749-62.

116. Zhou Y, Hileman EO, Plunkett W, Keating MJ, Huang P. Free radical stress in chronic lymphocytic leukemia cells and its role in cellular sensitivity to ROSgenerating anticancer agents. Blood. 2003;101(10):4098-104.

117. Hileman EO, Liu J, Albitar M, Keating MJ, Huang P. Intrinsic oxidative stress in cancer cells: a biochemical basis for therapeutic selectivity. Cancer Chemother Pharmacol. 2004;53(3):209-19.

118. Powis G, Montfort WR. Properties and biological activities of thioredoxins. Annual review of biophysics and biomolecular structure. 2001;30:421-55.

119. Lee S, Kim SM, Lee RT. Thioredoxin and thioredoxin target proteins: from molecular mechanisms to functional significance. Antioxidants \& redox signaling. 2013;18(10):1165-207.

120. Zhang W, Trachootham D, Liu J, Chen G, Pelicano H, Garcia-Prieto C, et al. Stromal control of cystine metabolism promotes cancer cell survival in chronic lymphocytic leukaemia. Nat Cell Biol. 2012;14(3):276-86.

121. Lanham S, Hamblin T, Oscier D, Ibbotson R, Stevenson F, Packham G. Differential signaling via surface IgM is associated with $\mathrm{VH}$ gene mutational status and CD38 expression in chronic lymphocytic leukemia. Blood. 2003;101(3):1087-93. 
122.

Mockridge CI, Potter KN, Wheatley I, Neville LA, Packham G, Stevenson FK.

Reversible anergy of sIgM-mediated signaling in the two subsets of CLL defined by VH-gene mutational status. Blood. 2007;109(10):4424-31.

123. Muzio M, Apollonio B, Scielzo C, Frenquelli M, Vandoni I, Boussiotis V, et al. Constitutive activation of distinct BCR-signaling pathways in a subset of CLL patients: a molecular signature of anergy. Blood. 2008;112(1):188-95.

124. Hobeika E, Nielsen PJ, Medgyesi D. Signaling mechanisms regulating Blymphocyte activation and tolerance. J Mol Med (Berl). 2015;93(2):143-58.

125. Adachi T, Wienands J, Wakabayashi C, Yakura H, Reth M, Tsubata T. SHP-1 requires inhibitory co-receptors to down-modulate B cell antigen receptor-mediated phosphorylation of cellular substrates. The Journal of biological chemistry. 2001;276(28):26648-55.

126. Contri A, Brunati AM, Trentin L, Cabrelle A, Miorin M, Cesaro L, et al. Chronic lymphocytic leukemia B cells contain anomalous Lyn tyrosine kinase, a putative contribution to defective apoptosis. The Journal of clinical investigation. 2005;115(2):369-78.

127. Gobessi S, Laurenti L, Longo PG, Carsetti L, Berno V, Sica S, et al. Inhibition of constitutive and BCR-induced Syk activation downregulates Mcl-1 and induces apoptosis in chronic lymphocytic leukemia B cells. Leukemia. 2009;23(4):686-97.

128. Ringshausen I, Schneller F, Bogner C, Hipp S, Duyster J, Peschel C, et al. Constitutively activated phosphatidylinositol-3 kinase (PI-3K) is involved in the defect of apoptosis in B-CLL: association with protein kinase Cdelta. Blood. 2002;100(10):3741-8.

129. Barragan M, Bellosillo B, Campas C, Colomer D, Pons G, Gil J. Involvement of protein kinase $\mathrm{C}$ and phosphatidylinositol 3-kinase pathways in the survival of $\mathrm{B}$-cell chronic lymphocytic leukemia cells. Blood. 2002;99(8):2969-76.

130. Ntoufa S, Vardi A, Papakonstantinou N, Anagnostopoulos A, AleporouMarinou V, Belessi C, et al. Distinct innate immunity pathways to activation and tolerance in subgroups of chronic lymphocytic leukemia with distinct immunoglobulin receptors. Molecular medicine. 2012;18:1281-91.

131. Lanzavecchia A, Sallusto F. Toll-like receptors and innate immunity in B-cell activation and antibody responses. Current opinion in immunology. 2007;19(3):26874. 
132.

Muzio M, Scielzo C, Bertilaccio MT, Frenquelli M, Ghia P, Caligaris-Cappio F.

Expression and function of toll like receptors in chronic lymphocytic leukaemia cells. British journal of haematology. 2009;144(4):507-16.

133. Bernasconi NL, Onai N, Lanzavecchia A. A role for Toll-like receptors in acquired immunity: up-regulation of TLR9 by BCR triggering in naive B cells and constitutive expression in memory B cells. Blood. 2003;101(11):4500-4.

134. Bourke E, Bosisio D, Golay J, Polentarutti N, Mantovani A. The toll-like receptor repertoire of human B lymphocytes: inducible and selective expression of TLR9 and TLR10 in normal and transformed cells. Blood. 2003;102(3):956-63.

135. Hashimoto S, Dono M, Wakai M, Allen SL, Lichtman SM, Schulman P, et al. Somatic diversification and selection of immunoglobulin heavy and light chain variable region genes in IgG+ CD5+ chronic lymphocytic leukemia B cells. The Journal of experimental medicine. 1995;181(4):1507-17.

136. Fais F, Ghiotto F, Hashimoto S, Sellars B, Valetto A, Allen SL, et al. Chronic lymphocytic leukemia B cells express restricted sets of mutated and unmutated antigen receptors. The Journal of clinical investigation. 1998;102(8):1515-25.

137. Messmer BT, Albesiano E, Efremov DG, Ghiotto F, Allen SL, Kolitz J, et al. Multiple distinct sets of stereotyped antigen receptors indicate a role for antigen in promoting chronic lymphocytic leukemia. The Journal of experimental medicine. 2004;200(4):519-25.

138. Widhopf GF, 2nd, Rassenti LZ, Toy TL, Gribben JG, Wierda WG, Kipps TJ. Chronic lymphocytic leukemia B cells of more than $1 \%$ of patients express virtually identical immunoglobulins. Blood. 2004;104(8):2499-504.

139. Darzentas N, Hadzidimitriou A, Murray F, Hatzi K, Josefsson P, Laoutaris N, et al. A different ontogenesis for chronic lymphocytic leukemia cases carrying stereotyped antigen receptors: molecular and computational evidence. Leukemia. 2010;24(1):125-32.

140. Agathangelidis A, Darzentas N, Hadzidimitriou A, Brochet X, Murray F, Yan $\mathrm{XJ}$, et al. Stereotyped B-cell receptors in one-third of chronic lymphocytic leukemia: a molecular classification with implications for targeted therapies. Blood. 2012;119(19):4467-75. 
141. Rossi D, Spina V, Bomben R, Rasi S, Dal-Bo M, Bruscaggin A, et al. Association between molecular lesions and specific B-cell receptor subsets in chronic lymphocytic leukemia. Blood. 2013;121(24):4902-5.

142. Broker BM, Klajman A, Youinou P, Jouquan J, Worman CP, Murphy J, et al. Chronic lymphocytic leukemic (CLL) cells secrete multispecific autoantibodies. Journal of autoimmunity. 1988;1(5):469-81.

143. Sthoeger ZM, Wakai M, Tse DB, Vinciguerra VP, Allen SL, Budman DR, et al. Production of autoantibodies by CD5-expressing B lymphocytes from patients with chronic lymphocytic leukemia. The Journal of experimental medicine. 1989;169(1):255-68.

144. Herve M, Xu K, Ng YS, Wardemann H, Albesiano E, Messmer BT, et al. Unmutated and mutated chronic lymphocytic leukemias derive from self-reactive $B$ cell precursors despite expressing different antibody reactivity. The Journal of clinical investigation. 2005;115(6):1636-43.

145. Lanemo Myhrinder A, Hellqvist E, Sidorova E, Soderberg A, Baxendale H, Dahle C, et al. A new perspective: molecular motifs on oxidized LDL, apoptotic cells, and bacteria are targets for chronic lymphocytic leukemia antibodies. Blood. 2008;111(7):3838-48.

146. Chu CC, Catera R, Hatzi K, Yan XJ, Zhang L, Wang XB, et al. Chronic lymphocytic leukemia antibodies with a common stereotypic rearrangement recognize nonmuscle myosin heavy chain IIA. Blood. 2008;112(13):5122-9.

147. Catera R, Silverman GJ, Hatzi K, Seiler T, Didier S, Zhang L, et al. Chronic lymphocytic leukemia cells recognize conserved epitopes associated with apoptosis and oxidation. Molecular medicine (Cambridge, Mass. 2008;14(11-12):665-74

148. Hoogeboom R, van Kessel KP, Hochstenbach F, Wormhoudt TA, Reinten RJ, Wagner $\mathrm{K}$, et al. A mutated B cell chronic lymphocytic leukemia subset that recognizes and responds to fungi. The Journal of experimental medicine. 2013;210(1):59-70.

149. Kostareli E, Hadzidimitriou A, Stavroyianni N, Darzentas N, Athanasiadou A, Gounari M, et al. Molecular evidence for EBV and CMV persistence in a subset of patients with chronic lymphocytic leukemia expressing stereotyped IGHV4-34 B-cell receptors. Leukemia. 2009;23(5):919-24. 
150. Duhren-von Minden M, Ubelhart R, Schneider D, Wossning T, Bach MP, Buchner M, et al. Chronic lymphocytic leukaemia is driven by antigen-independent cell-autonomous signalling. Nature. 2012;489(7415):309-12.

151. Iacovelli S, Hug E, Bennardo S, Duehren-von Minden M, Gobessi S, Rinaldi A, et al. Two types of BCR interactions are positively selected during leukemia development in the Emu-TCL1 transgenic mouse model of CLL. Blood. 2015;125(10):1578-88.

152. Klein U, Tu Y, Stolovitzky GA, Mattioli M, Cattoretti G, Husson H, et al. Gene expression profiling of B cell chronic lymphocytic leukemia reveals a homogeneous phenotype related to memory B cells. The Journal of experimental medicine. 2001;194(11):1625-38.

153. Martin F, Kearney JF. B1 cells: similarities and differences with other B cell subsets. Current opinion in immunology. 2001;13(2):195-201.

154. Stall AM, Farinas MC, Tarlinton DM, Lalor PA, Herzenberg LA, Strober S, et al. Ly-1 B-cell clones similar to human chronic lymphocytic leukemias routinely develop in older normal mice and young autoimmune (New Zealand Black-related) animals. Proceedings of the National Academy of Sciences of the United States of America. 1988;85(19):7312-6.

155. Chung JB, Silverman M, Monroe JG. Transitional B cells: step by step towards immune competence. Trends in immunology. 2003;24(6):343-9.

156. Sims GP, Ettinger R, Shirota Y, Yarboro CH, Illei GG, Lipsky PE. Identification and characterization of circulating human transitional $B$ cells. Blood. 2005;105(11):4390-8.

157. Chiorazzi N, Ferrarini M. Cellular origin(s) of chronic lymphocytic leukemia: cautionary notes and additional considerations and possibilities. Blood. 2011;117(6):1781-91.

158. Sharma S, Kelly TK, Jones PA. Epigenetics in cancer. Carcinogenesis. 2010;31(1):27-36.

159. Jones PA, Baylin SB. The epigenomics of cancer. Cell. 2007;128(4):683-92.

160. Esteller M. Cancer epigenomics: DNA methylomes and histone-modification maps. Nature reviews Genetics. 2007;8(4):286-98. 
161. Wahlfors J, Hiltunen H, Heinonen K, Hamalainen E, Alhonen L, Janne J. Genomic hypomethylation in human chronic lymphocytic leukemia. Blood. 1992;80(8):2074-80.

162. Raval A, Lucas DM, Matkovic JJ, Bennett KL, Liyanarachchi S, Young DC, et al. TWIST2 demonstrates differential methylation in immunoglobulin variable heavy chain mutated and unmutated chronic lymphocytic leukemia. Journal of clinical oncology : official journal of the American Society of Clinical Oncology. 2005;23(17):3877-85.

163. Strathdee G, Sim A, Parker A, Oscier D, Brown R. Promoter hypermethylation silences expression of the HoxA4 gene and correlates with IgVh mutational status in CLL. Leukemia. 2006;20(7):1326-9.

164. Corcoran M, Parker A, Orchard J, Davis Z, Wirtz M, Schmitz OJ, et al. ZAP-70 methylation status is associated with ZAP-70 expression status in chronic lymphocytic leukemia. Haematologica. 2005;90(8):1078-88.

165. Kanduri M, Cahill N, Goransson H, Enstrom C, Ryan F, Isaksson A, et al. Differential genome-wide array-based methylation profiles in prognostic subsets of chronic lymphocytic leukemia. Blood. 2010;115(2):296-305.

166. Kanduri M, Marincevic M, Halldorsdottir AM, Mansouri L, Junevik K, Ntoufa S, et al. Distinct transcriptional control in major immunogenetic subsets of chronic lymphocytic leukemia exhibiting subset-biased global DNA methylation profiles. Epigenetics : official journal of the DNA Methylation Society. 2012;7(12):1435-42.

167. Kulis M, Heath S, Bibikova M, Queiros AC, Navarro A, Clot G, et al. Epigenomic analysis detects widespread gene-body DNA hypomethylation in chronic lymphocytic leukemia. Nature genetics. 2012;44(11):1236-42.

168. Queiros AC, Villamor N, Clot G, Martinez-Trillos A, Kulis M, Navarro A, et al. A B-cell epigenetic signature defines three biologic subgroups of chronic lymphocytic leukemia with clinical impact. Leukemia. 2015;29(3):598-605.

169. Calin GA, Liu CG, Sevignani C, Ferracin M, Felli N, Dumitru CD, et al. MicroRNA profiling reveals distinct signatures in B cell chronic lymphocytic leukemias. Proceedings of the National Academy of Sciences of the United States of America. 2004;101(32):11755-60. 
170. Fulci V, Chiaretti S, Goldoni M, Azzalin G, Carucci N, Tavolaro S, et al. Quantitative technologies establish a novel microRNA profile of chronic lymphocytic leukemia. Blood. 2007;109(11):4944-51.

171. Klein U, Lia M, Crespo M, Siegel R, Shen Q, Mo T, et al. The DLEU2/miR15a/16-1 cluster controls $B$ cell proliferation and its deletion leads to chronic lymphocytic leukemia. Cancer Cell. 2010;17(1):28-40.

172. Baer C, Claus R, Frenzel LP, Zucknick M, Park YJ, Gu L, et al. Extensive promoter DNA hypermethylation and hypomethylation is associated with aberrant microRNA expression in chronic lymphocytic leukemia. Cancer research. 2012;72(15):3775-85.

173. Silverman LR, Demakos EP, Peterson BL, Kornblith AB, Holland JC, Odchimar-Reissig R, et al. Randomized controlled trial of azacitidine in patients with the myelodysplastic syndrome: a study of the cancer and leukemia group B. Journal of clinical oncology : official journal of the American Society of Clinical Oncology. 2002;20(10):2429-40.

174. Lefranc MP, Giudicelli V, Ginestoux C, Jabado-Michaloud J, Folch G, Bellahcene F, et al. IMGT, the international ImMunoGeneTics information system. Nucleic acids research. 2009;37(Database issue):D1006-12.

175. Gromer S, Urig S, Becker K. The thioredoxin system--from science to clinic. Medicinal research reviews. 2004;24(1):40-89.

176. Nilsson J, Soderberg O, Nilsson K, Rosen A. Thioredoxin prolongs survival of B-type chronic lymphocytic leukemia cells. Blood. 2000;95(4):1420-6.

177. Saitoh M, Nishitoh H, Fujii M, Takeda K, Tobiume K, Sawada Y, et al. Mammalian thioredoxin is a direct inhibitor of apoptosis signal-regulating kinase (ASK) 1. The EMBO journal. 1998;17(9):2596-606.

178. Watson JA, Rumsby MG, Wolowacz RG. Phage display identifies thioredoxin and superoxide dismutase as novel protein kinase C-interacting proteins: thioredoxin inhibits protein kinase C-mediated phosphorylation of histone. The Biochemical journal. 1999;343 Pt 2:301-5.

179. Hayashi T, Ueno Y, Okamoto T. Oxidoreductive regulation of nuclear factor kappa B. Involvement of a cellular reducing catalyst thioredoxin. The Journal of biological chemistry. 1993;268(15):11380-8. 
180. Makino Y, Yoshikawa N, Okamoto K, Hirota K, Yodoi J, Makino I, et al. Direct association with thioredoxin allows redox regulation of glucocorticoid receptor function. The Journal of biological chemistry. 1999;274(5):3182-8.

181. Ueno M, Masutani H, Arai RJ, Yamauchi A, Hirota K, Sakai T, et al. Thioredoxin-dependent redox regulation of p53-mediated p21 activation. The Journal of biological chemistry. 1999;274(50):35809-15.

182. Silber JR, Bobola MS, Blank A, Schoeler KD, Haroldson PD, Huynh MB, et al. The apurinic/apyrimidinic endonuclease activity of Ape1/Ref-1 contributes to human glioma cell resistance to alkylating agents and is elevated by oxidative stress. Clinical cancer research : an official journal of the American Association for Cancer Research. 2002;8(9):3008-18.

183. Hirota K, Matsui M, Iwata S, Nishiyama A, Mori K, Yodoi J. AP-1 transcriptional activity is regulated by a direct association between thioredoxin and Ref-1. Proceedings of the National Academy of Sciences of the United States of America. 1997;94(8):3633-8.

184. Tangye SG, Raison RL. Human cytokines suppress apoptosis of leukaemic CD5+ B cells and preserve expression of bcl-2. Immunology and cell biology. 1997;75(2):127-35.

185. Schwertassek U, Balmer Y, Gutscher M, Weingarten L, Preuss M, Engelhard J, et al. Selective redox regulation of cytokine receptor signaling by extracellular thioredoxin-1. The EMBO journal. 2007;26(13):3086-97.

186. Hansen HP, Dietrich S, Kisseleva T, Mokros T, Mentlein R, Lange HH, et al. CD30 shedding from Karpas 299 lymphoma cells is mediated by TNF-alphaconverting enzyme. Journal of immunology. 2000;165(12):6703-9.

187. Baker A, Payne CM, Briehl MM, Powis G. Thioredoxin, a gene found overexpressed in human cancer, inhibits apoptosis in vitro and in vivo. Cancer research. 1997;57(22):5162-7.

188. Li C, Thompson MA, Tamayo AT, Zuo Z, Lee J, Vega F, et al. Over-expression of Thioredoxin-1 mediates growth, survival, and chemoresistance and is a druggable target in diffuse large B-cell lymphoma. Oncotarget. 2012;3(3):314-26.

189. Welsh SJ, Bellamy WT, Briehl MM, Powis G. The redox protein thioredoxin-1 (Trx-1) increases hypoxia-inducible factor 1alpha protein expression: Trx-1 
overexpression results in increased vascular endothelial growth factor production and enhanced tumor angiogenesis. Cancer research. 2002;62(17):5089-95.

190. Ramanathan RK, Kirkpatrick DL, Belani CP, Friedland D, Green SB, Chow HH, et al. A Phase I pharmacokinetic and pharmacodynamic study of PX-12, a novel inhibitor of thioredoxin-1, in patients with advanced solid tumors. Clinical cancer research : an official journal of the American Association for Cancer Research. 2007;13(7):2109-14.

191. Ramanathan RK, Abbruzzese J, Dragovich T, Kirkpatrick L, Guillen JM, Baker $\mathrm{AF}$, et al. A randomized phase II study of PX-12, an inhibitor of thioredoxin in patients with advanced cancer of the pancreas following progression after a gemcitabinecontaining combination. Cancer Chemother Pharmacol. 2011;67(3):503-9.

192. Baker AF, Adab KN, Raghunand N, Chow HH, Stratton SP, Squire SW, et al. A phase IB trial of 24-hour intravenous PX-12, a thioredoxin-1 inhibitor, in patients with advanced gastrointestinal cancers. Invest New Drugs. 2013;31(3):631-41.

193. Sutton LA, Kostareli E, Hadzidimitriou A, Darzentas N, Tsaftaris A, Anagnostopoulos A, et al. Extensive intraclonal diversification in a subgroup of chronic lymphocytic leukemia patients with stereotyped IGHV4-34 receptors: implications for ongoing interactions with antigen. Blood. 2009;114(20):4460-8.

194. Kostareli E, Sutton LA, Hadzidimitriou A, Darzentas N, Kouvatsi A, Tsaftaris $A$, et al. Intraclonal diversification of immunoglobulin light chains in a subset of chronic lymphocytic leukemia alludes to antigen-driven clonal evolution. Leukemia. 2010;24(7):1317-24.

195. Potter KN, Mockridge CI, Neville L, Wheatley I, Schenk M, Orchard J, et al. Structural and functional features of the B-cell receptor in IgG-positive chronic lymphocytic leukemia. Clinical cancer research : an official journal of the American Association for Cancer Research. 2006;12(6):1672-9.

196. Chu CC, Catera R, Zhang L, Didier S, Agagnina BM, Damle RN, et al. Many chronic lymphocytic leukemia antibodies recognize apoptotic cells with exposed nonmuscle myosin heavy chain IIA: implications for patient outcome and cell of origin. Blood. 2010;115(19):3907-15.

197. Binder CJ, Shaw PX, Chang MK, Boullier A, Hartvigsen K, Horkko S, et al. The role of natural antibodies in atherogenesis. J Lipid Res. 2005;46(7):1353-63. 
198. Bomben R, Dal Bo M, Capello D, Forconi F, Maffei R, Laurenti L, et al. Molecular and clinical features of chronic lymphocytic leukaemia with stereotyped B cell receptors: results from an Italian multicentre study. British journal of haematology. 2009;144(4):492-506.

199. Apollonio B, Scielzo C, Bertilaccio MT, Ten Hacken E, Scarfo L, Ranghetti P, et al. Targeting B-cell anergy in chronic lymphocytic leukemia. Blood. 2013;121(19):3879-88, S1-8.

200. Efremov DG, Bomben R, Gobessi S, Gattei V. TLR9 signaling defines distinct prognostic subsets in CLL. Frontiers in bioscience. 2013;18:371-86.

201. Ruprecht CR, Lanzavecchia A. Toll-like receptor stimulation as a third signal required for activation of human naive B cells. European journal of immunology. 2006;36(4):810-6.

202. Rozkova D, Novotna L, Pytlik R, Hochova I, Kozak T, Bartunkova J, et al. Tolllike receptors on B-CLL cells: expression and functional consequences of their stimulation. Int J Cancer. 2010;126(5):1132-43.

203. Buhl AM, Jurlander J, Jorgensen FS, Ottesen AM, Cowland JB, Gjerdrum LM, et al. Identification of a gene on chromosome 12q22 uniquely overexpressed in chronic lymphocytic leukemia. Blood. 2006;107(7):2904-11.

204. Buhl AM, Jurlander J, Geisler CH, Pedersen LB, Andersen MK, Josefsson P, et al. CLLU1 expression levels predict time to initiation of therapy and overall survival in chronic lymphocytic leukemia. European journal of haematology. 2006;76(6):45564.

Heintel D, Kienle D, Shehata M, Krober A, Kroemer E, Schwarzinger I, et al. High expression of lipoprotein lipase in poor risk B-cell chronic lymphocytic leukemia. Leukemia. 2005;19(7):1216-23.

206. Gutierrez A, Jr., Tschumper RC, Wu X, Shanafelt TD, Eckel-Passow J, Huddleston PM, 3rd, et al. LEF-1 is a prosurvival factor in chronic lymphocytic leukemia and is expressed in the preleukemic state of monoclonal B-cell lymphocytosis. Blood. 2010;116(16):2975-83.

207. Saborit-Villarroya I, Vaisitti T, Rossi D, D'Arena G, Gaidano G, Malavasi F, et al. E2A is a transcriptional regulator of CD38 expression in chronic lymphocytic leukemia. Leukemia. 2011;25(3):479-88. 
208. Lenschow DJ, Sperling AI, Cooke MP, Freeman G, Rhee L, Decker DC, et al. Differential up-regulation of the B7-1 and B7-2 costimulatory molecules after Ig receptor engagement by antigen. Journal of immunology. 1994;153(5):1990-7.

209. Chaperot L, Plumas J, Jacob MC, Bost F, Molens JP, Sotto JJ, et al. Functional expression of CD80 and CD86 allows immunogenicity of malignant B cells from nonHodgkin's lymphomas. Experimental hematology. 1999;27(3):479-88.

210. Liu W, Quinto I, Chen X, Palmieri C, Rabin RL, Schwartz OM, et al. Direct inhibition of Bruton's tyrosine kinase by IBtk, a Btk-binding protein. Nature immunology. 2001;2(10):939-46.

211. Saborit-Villarroya I, Vaisitti T, Rossi D, D'Arena G, Gaidano G, Malavasi F, et al. E2A is a transcriptional regulator of CD38 expression in chronic lymphocytic leukemia. Leukemia.25(3):479-88.

212. Mansouri M, Sevov M, Fahlgren E, Tobin G, Jondal M, Osorio L, et al. Lipoprotein lipase is differentially expressed in prognostic subsets of chronic lymphocytic leukemia but displays invariably low catalytical activity. Leuk Res.34(3):301-6.

213. Kn H, Bassal S, Tikellis C, El-Osta A. Expression analysis of the epigenetic methyltransferases and methyl-CpG binding protein families in the normal B-cell and B-cell chronic lymphocytic leukemia (CLL). Cancer Biol Ther. 2004;3(10):989-94.

214. Moreno DA, Scrideli CA, Cortez MA, de Paula Queiroz R, Valera ET, da Silva Silveira V, et al. Differential expression of HDAC3, HDAC7 and HDAC9 is associated with prognosis and survival in childhood acute lymphoblastic leukaemia. Br J Haematol.150(6):665-73.

215. Matsuda S, Yokozaki S, Yoshida H, Kitagishi Y, Shirafuji N, Okumura N. Insulin receptor substrate protein 53 (IRSp53) as a binding partner of antimetastasis molecule NESH, a member of Abelson interactor protein family. Ann Oncol. 2008;19(7):1356-7.

216. Kleer CG, Zhang Y, Pan Q, van Golen KL, Wu ZF, Livant D, et al. WISP3 is a novel tumor suppressor gene of inflammatory breast cancer. Oncogene. 2002;21(20):3172-80.

217. Nagy B, Lundan T, Larramendy ML, Aalto Y, Zhu Y, Niini T, et al. Abnormal expression of apoptosis-related genes in haematological malignancies: 
overexpression of MYC is poor prognostic sign in mantle cell lymphoma. $\mathrm{Br} \mathrm{J}$ Haematol. 2003;120(3):434-41.

218. Ban EM, LeBoeuf RD. Suppressin: an endogenous negative regulator of immune cell activation. Immunol Res. 1994;13(1):1-9.

219. Osorio LM, Aguilar-Santelises M. Apoptosis in B-chronic lymphocytic leukaemia. Med Oncol. 1998;15(4):234-40.

220. Vargova K, Curik N, Burda P, Basova P, Kulvait V, Pospisil V, et al. MYB transcriptionally regulates the miR-155 host gene in chronic lymphocytic leukemia. Blood.117(14):3816-25.

221. Soderberg A, Hossain A, Rosen A. A protein disulfide isomerase/thioredoxin1 complex is physically attached to exofacial membrane tumor necrosis factor receptors: overexpression in chronic lymphocytic leukemia cells. Antioxidants \& redox signaling. 2013;18(4):363-75.

222. Kossev PM, Raghunath PN, Bagg A, Schuster S, Tomaszewski JE, Wasik MA. SHP-1 expression by malignant small B-cell lymphomas reflects the maturation stage of their normal B-cell counterparts. Am J Surg Pathol. 2001;25(7):949-55.

223. Wu C, Sun M, Liu L, Zhou GW. The function of the protein tyrosine phosphatase SHP-1 in cancer. Gene. 2003;306:1-12.

224. Bergh AC, Evaldsson C, Pedersen LB, Geisler C, Stamatopoulos K, Rosenquist $\mathrm{R}$, et al. Silenced B-cell receptor response to autoantigen in a poor-prognostic subset of chronic lymphocytic leukemia. Haematologica. 2014;99(11):1722-30.

225. Negro R, Gobessi S, Longo PG, He Y, Zhang ZY, Laurenti L, et al. Overexpression of the autoimmunity-associated phosphatase PTPN22 promotes survival of antigen-stimulated CLL cells by selectively activating AKT. Blood. 2012;119(26):6278-87.

226. Tibaldi E, Brunati AM, Zonta F, Frezzato F, Gattazzo C, Zambello R, et al. Lynmediated SHP-1 recruitment to CD5 contributes to resistance to apoptosis of B-cell chronic lymphocytic leukemia cells. Leukemia. 2011;25(11):1768-81.

227. Lorenz U. SHP-1 and SHP-2 in T cells: two phosphatases functioning at many levels. Immunological reviews. 2009;228(1):342-59.

228. Poole AW, Jones ML. A SHPing tale: perspectives on the regulation of SHP-1 and SHP-2 tyrosine phosphatases by the C-terminal tail. Cell Signal. 2005;17(11):1323-32. 
229. Sen G, Bikah G, Venkataraman C, Bondada S. Negative regulation of antigen receptor-mediated signaling by constitutive association of CD5 with the SHP-1 protein tyrosine phosphatase in B-1 B cells. European journal of immunology. 1999;29(10):3319-28.

230. Rosén A, Bergh AC, Gogolak P, Evaldsson C, Myhrinder AL, Hellqvist E, et al. Lymphoblastoid cell line with B1 cell characteristics established from a chronic lymphocytic leukemia clone by in vitro EBV infection. OncoImmunology. 2012;1(1):18-27. 



\section{Papers}

The articles associated with this thesis have been removed for copyright reasons. For more details about these see:

http://urn.kb.se/resolve?urn=urn:nbn:se:liu:diva-124576 